No. 6 april 2005

Axel Dreher

Does Globalization Affect Growth? Evidence from a new Index of Globalization

Research Paper Series

Thurgauer Wirtschaftsinstitut 


\title{
Does Globalization Affect Growth? Evidence from a new Index of Globalization
}

\author{
Axel Dreher \\ dreher@twi-kreuzlingen.ch \\ TWI and University of Konstanz
}

ABSTRACT

april 2005

The paper presents an index of globalization covering its three main dimensions: economic integration, social integration, and political integration. Using panel data for 123 countries in 1970-2000 it is analyzed empirically whether the overall index of globalization as well as sub-indexes constructed to measure the single dimensions affect economic growth. As the results show, globalization indeed promotes growth. The dimensions most robustly related with growth refer to actual economic flows and restrictions in developed countries. Although less robustly, information flows also promote growth whereas political integration has no effect.

Keywords: Measurement of Globalization, Growth

JEL: F02, F43, C82, H77, O57

Address: Hauptstraße 90, 8280 Kreuzlingen, Switzerland

The author thanks Bernhard Boockmann, Christos Kotsogiannis, Quan Li, Verena Liessem, Fulvio Mulatero, Torsten Saadma and seminar participants at the ENTER Jamboree Meeting 2003, the Passau Workshop 'Internationale Wirtschaftsbeziehungen', the 6th Annual Conference on Global Economic Analysis, the European Economic Association (2003), the Verein fuer Socialpolitik (2003) and the universities of Goettingen, Universidad de las Americas and Exeter for valuable comments. 


\section{Introduction}

Many non-economists expect the costs associated with globalization to exceed its benefits. Fears of an erosion of social and environmental standards, high poverty rates in less developed countries and ever higher frequencies of financial crisis resulted in protests like that in Seattle in 1999. Quite the contrary, most economists strongly believe the net effect of globalization to be positive. Apart from economic theory, this optimism is supported by empirical studies as well. To measure globalization, most of these studies employed proxies like trade and capital flows or openness to these flows. Using these proxies, Beer and Boswell (2001) examined the consequences of globalization on inequality. Li and Reuveny (2003) analyzed their effects on democracy. As Heinemann (2000) shows, more globalized countries have lower increases in government outlays and taxes. Vaubel (1999) found them to have lower government consumption.

The effects of globalization on growth have also been frequently analyzed with these measures. Until most recently, however, most studies examined them employing cross sections only. For example, Chanda (2001) uses an index of capital account openness to show that more developing countries have suffered from globalization than not, while Rodrik (1998) as well as Alesina et al. (1994) found no effect of capital account openness on economic growth. ${ }^{1}$ With respect to foreign direct investment (fdi) there is evidence of a positive growth-effect in countries which are sufficiently rich (Blomström et al. 1992) and a negative one in low income countries (Garrett 2001). ${ }^{2}$ Among others, Dollar (1992) analyzed the relationship between economic performance and openness to trade, Frankel and Romer (1996) those between growth and actual flows. Their results show that both openness to trade and actual trade flows are robustly related to growth. All of these studies present, however, only cross sectional estimates. Moreover, they do not adequately control for endogeneity. Their results might therefore reflect unobserved characteristics which do not vary over time instead of being the consequences of globalization or might reflect reverse causality. ${ }^{3}$

Aware of the shortcomings of the cross-section approach, some recent studies use panel data to examine the relationship between some dimensions of globalization and growth. Among them, Dollar and Kraay (2001) found that an increase in trade flows and foreign direct investment resulted in higher growth rates. Greenaway et al. (1999) also report a strong relationship between trade and growth. With respect to fdi, Borensztein et al. (1998) provide

\footnotetext{
${ }^{1}$ Edison et al. (2002) summarize the literature on capital account liberalization and economic performance.

${ }^{2}$ Studies examining the effects of foreign direct investment on countries' growth rates have been summarized by Durham (2000).
} 
evidence of a positive growth-effect - given a minimum threshold stock of human capital. Carkovic and Levine (2002), to the contrary, do not find a robust influence of foreign direct investment on growth. A detailed analysis of the impact of several indicators of financial integration and growth is provided by Edison et al. (2002a). Their results show that no robust relationship exists.

While those studies provide very detailed analysis of individual sub-dimensions of globalization, none of them examines the consequences of globalization on economic growth in greater detail. ${ }^{4}$ The effects reported might therefore appear only because other important aspects of globalization are omitted from the regressions. Most dimensions of globalization are strongly related to each other, so including them separately in a regression induces collinearity problems. Excluding those dimensions which are not the primary focus of the analysis - the method preferred in the literature - can, however, severely bias the coefficients estimated. Moreover, it is not obvious that all dimensions of globalization affect economic performance in the same direction. Since the overall effects of globalization are what matters, the lack of an overall measure and an analysis of its relationship with growth is a serious omission. The only study trying to measure overall globalization is A.T. Kearney/Foreign Policy Magazine (2002). They calculated a globalization ranking using various subgroups. Their ranking is, however, only available for three years. Moreover, important dimensions of globalization are omitted. The measure can therefore not be used in an empirical investigation.

This paper does not try to give specific policy advice. It tries to contribute to the literature in examining the overall effects of several dimensions of globalization on growth empirically in a time-series cross-section context. Since many of these dimensions are highly correlated, it is impossible to include them all individually in one regression. Therefore, the paper develops an index of globalization covering its most important aspects: economic integration, social integration and political integration. To measure these dimensions, 23 variables have been combined to three sub-indexes using an objective statistical method. The sub-indexes are in turn aggregated into one single index of globalization.

The remainder of the paper is structured as follows. First, I present the methodology and rationale of the index and present some results. I proceed by analyzing empirically the relationship between this index and economic growth. The final section draws conclusions.

\footnotetext{
${ }^{3}$ Dollar and Kraay (2001: 13) summarize criticisms of this approach.

${ }^{4}$ For a detailed analysis of the several dimensions of globalization on economic policies in the OECD countries see Dreher (2005).
} 


\section{Methodology and Rationale of the Index}

Throughout the paper globalization is meant to describe the process of creating networks of connections among actors at multicontinental distances, mediated through a variety of flows including people, information and ideas, capital, and goods (Clark 2000: 86). It is a process that erodes national boundaries, integrates national economies, cultures, technologies and governance, and produces complex relations of mutual interdependence (Norris 2000: 155). Among others Keohane and Nye (2000: 4) highlight the following dimensions of globalization:

- economic globalization, characterized as long distance flows of goods, capital and services as well as information and perceptions that accompany market exchanges,

- political globalization, characterized by a diffusion of government policies and

- social globalization, expressed as the spread of ideas, information, images, and people.

To measure the degree of economic globalization, two indexes are constructed. One index measures actual flows: trade, foreign direct investment and portfolio investment (all in percent of GDP). Income payments to foreign nationals and capital employed (in percent of GDP) are included to proxy for the extent a country employs foreign people and capital in its production processes. The second index measures restrictions on trade and capital using hidden import barriers, mean tariff rates, taxes on international trade (as a share of current revenue) and an index of capital controls. Given a certain level of trade, a country with higher revenues from trade taxes is less globalized. To proxy restrictions of the capital account most previous studies employed rather crude measures. ${ }^{5}$ Rodrik (1998) used the proportion of years for which the capital account was free of restrictions. Alesina et al. (1994) coded a 0-1 dummy variable. Since openness is not a yes-or-no question - it can and does occur in differing degrees in different countries - I employ an index constructed by Gwartney and Lawson (2002). It is based on the IMF's Annual Report on Exchange Arrangements and Exchange Restrictions and includes 13 different types of capital controls. The index is constructed by subtracting the number of restriction from 13 and multiplying the result by 10 .

The data on actual flows and on restrictions are aggregated into two sub-indexes and one overall index as described below. All variables, their precise definitions and data sources are listed in the appendix.

\footnotetext{
${ }^{5}$ An exception is Garrett (2001) who employs a ten scale indicator constructed by Brune (2000). He does, however, only report cross-section results.
} 
To proxy the degree of political globalization, the number of embassies in a country, the number of international organizations to which the country is a member and the number of UN peace missions a country participated in are used. ${ }^{6}$

The aspects of globalization that are hardest to pin down relate to the flow of information and ideas. According to Keohane and Nye (2000: 4), these constitute, however, the most pervasive form of globalism. Therefore, they necessarily have to be included in an index of globalization. I measure these flows distinguishing between three categories: data on personal contacts, data on information flows and data on cultural proximity. To proxy flows of information and personal contacts I use measures like international tourism, internet users, and number of radios, among others. The variables are shown in Table 1. Like Saich (2000: 209), I interpret cultural globalization as the domination of American cultural products. This is because the United States is the pacesetter in much of the global social-cultural realm (Rosendorf 2000: 111). Cultural proximity could be proxied by the number of English songs in national hit lists or movies shown in national cinemas that originated in Hollywood. However, the only proxy available is the number of McDonald's restaurants located in a country.

To construct the proxies for the empirical analysis, each variable is transformed to an index with a zero to ten scale, whereas higher values denote more globalization. When higher values of the original variable indicate higher globalization, the formula $\left(\left(\mathrm{V}_{\mathrm{i}}-\mathrm{V}_{\min }\right) /\left(\mathrm{V}_{\max }{ }^{-}\right.\right.$ $\left.\mathrm{V}_{\min }\right)^{* 10}$ ) has been used for transformation. Conversely, when higher values indicate less globalization, the formula is $\left(\left(\mathrm{V}_{\max }-\mathrm{V}_{\mathrm{i}}\right) /\left(\mathrm{V}_{\max }-\mathrm{V}_{\min }\right) * 10\right)$. This is the procedure employed by Gwartney and Lawson (2001) in the construction of their economic freedom index. The weights for the sub-indexes are calculated using principal components analysis. ${ }^{7}$ The year 2000 is used as the base year. For this year, the analysis partitions the variance of the variables used. The weights are then determined in a way that maximizes the variation of the resulting principal component. Therefore, the index captures the variation as fully as possible. As Gwartney and Lawson (2001: 7) point out, this procedure is particularly appropriate when several sub-components measure different aspects of a principal component. I applied the same procedure to the overall index.

If possible, the weights determined for the base year are then used to calculate the indexes for each single year back to 1970 . Where no data are available, the weights are readjusted to correct for this. Since the aim of the paper is to examine longer run changes, the

\footnotetext{
${ }^{6}$ Those variables have been proposed by A.T.Kearney/Foreign Policy Magazine (2000) to proxy political engagement.
} 
yearly indexes are averaged over five years. ${ }^{8}$ This is consistent with the analysis of Barro (1997).

The weights for the sub-indexes are presented in Table 1. Table 2 shows the results for the 2000 indexes as well as the overall indexes for 1975 and $1990 .{ }^{9}$ They are ranked by the overall index in 2000. According to this index, the world's most globalized country is the USA with a score of 6.48. This result is driven by high social and political integration with the rest of the world. To the contrary, the USA are ranked only $25^{\text {th }}$ with respect to economic integration. According to the index, France has the highest political integration with the rest of the world, followed by the USA, Sweden and Canada. Other countries ranking high on the overall index include countries like Sweden and Luxembourg. While Hong Kong and Singapore are ranked second and third, respectively, in terms of actual economic flows (not reported in the Table), overall, they are ranked much lower. This is mainly due to their low political integration with the rest of the world. According to the political integration index, Hong Kong is the country with the lowest score. Since Hong Kong now belongs to China, this is obvious. The Table also shows, that overall the world's least globalized country is Rwanda, with an index of 0.92 . This country has been destroyed by civil war and bad institutions. Its GDP per capita growth rate has been highly volatile over the last years, ranging between minus 4 percent in 1997 and plus 3 percent in 2000. It is politically isolated with only 16 incountry-embassies in 2000 and membership in 32 international inter-governmental organizations. Its sum of exports and imports amounts to 32 percent of its GDP, foreign direct investment inflows have been less than 1 percent of GDP in the same year. Capital transactions are controlled heavily (IMF 1998).

The country least integrated in economic terms is Togo, with fdi inflows amounting to 4 percent of GDP in 1999 and a heavily restricted capital account. Nepal has the lowest social globalization score. It had 21 in-country embassies in 2000 and was member in 30 intergovernmental organizations. Per 1000 capita, 12 daily newspapers have been published and, on average, each citizen talked 1.1 minutes with people in another country in 2000 per phone.

The next section analyzes the influence of these dimensions of globalization on economic growth.

\footnotetext{
${ }^{7}$ A similar methodology has been suggested by Lockwood (2004), testing for the robustness of the Kearny/ Foreign Policy Index of globalization.

${ }^{8}$ In some cases, data are only available in five year intervals. In these cases, data refer to the end of the five year period.

${ }^{9}$ Due to space restraints, the other results are not reproduced in the Table. They are available from the author.
} 


\section{Empirical Estimates}

Table 3 gives first evidence on the relationship between growth and globalization. The countries are separated into two sub-samples according to their overall index score. The mean of 2.45 of the index is used to draw the line between more and less globalized countries. As can be seen, more globalized countries grew faster in every five-year-period. A t-test shows that the hypothesis of equal means can be rejected between 1986-1990 and 1996-2000. To analyze this relationship in greater detail, pooled time-series cross-section regressions are conducted. The dependent variable is the growth rate of per capita GDP. The data are averages over five years and cover the time period 1970-2000. They extend to 123 countries. Since some of the data are not available for all countries or years, the panel data are unbalanced and the number of observations depends on the choice of explanatory variables. To account for time-invariant unobservable heterogeneity potentially correlated with the regressors, I use a fixed effects specification. A dummy for each of the five-year-periods is also included. All standard errors are estimated robustly. All variables, their precise definitions and data sources are listed in the appendix.

The first column of Table 4 includes variables typically employed in growth regressions (e.g. Barro 1997). The initial level of GDP per capita at each of the five-year periods is included to measure the conditional rate of convergence to the steady state growth rate. Secondary school enrolment and the log of life expectancy are employed as indicators of human capital. Since higher population growth should directly lead to lower per capita economic growth, the log of the fertility rate is also included. Higher domestic investment as a share of GDP should lead to higher growth rates whereas the effect of higher government consumption is not obvious a priori. On the one hand, a large government sector may induce inefficiencies and crowd out the private sector. On the other, the provision of an efficient infrastructure and a proper legal framework may promote growth (Hansson 2000). To account for the quality of the legal system and the enforceability of property rights, a rule of law index constructed by Gwartney and Lawson (2002) is included in the regression. Obviously, better institutions should promote growth. Finally, I include the change in a country's terms of trade and its rate of inflation. Both have been shown to have a significant effect on growth in previous studies.

Most results do qualitatively correspond to those of Barro (1997). Higher initial GDP is significantly associated with lower growth rates. Higher government consumption over GDP also leads to lower growth. The same is true for low investment and high inflation. 
Growth rates are higher with better institutions and higher school enrollment. Whereas the coefficients of those variables are significant at the five percent level at least, the coefficient of a change in a country's terms of trade is only marginally significant, with a positive sign. Life expectancy and fertility rates do not significantly influence economic growth.

Column 2 includes the overall index of globalization. As can be seen, its coefficient is positive and significant at the one percent level. The coefficient of the index shows that a one point increase would expand GDP per capita growth by 1.09 percentage points. For example, if Latvia was as integrated with the world as Spain, all else equal it could raise its growth rate from currently 5.94 to 7.1 percent. This could be achieved by increasing inflows of foreign direct investment from 7 to 27 percent of GDP, exports plus imports (in percent of GDP) from 107 to 140 percent and portfolio investment (in percent of GDP) from 5 to 30 percent. The same difference is between Italy and the United Kingdom while increasing the globalization index of Zimbabwe to those of the USA would increase the Zimbabwean growth rate by 4.64 percentage points. The rule of law index is only significant at the ten percent level while changes in the terms of trade are now completely insignificant. The regression includes 106 countries with an average of 4.1 observations. It explains 44 percent of the within-groups variation.

King and Levine (1993) argue that the quality of a country's financial markets can influence economic growth. In column 3, variables to account for this quality are included. Liquid liabilities are a typical measure of the financial depth and thus of the overall size of the financial sector, stock market capitalization (relative to GDP) is an indicator of the size of the stock market. However, confirming the results of Chanda (2001), these variables are completely insignificant. Due to missing data, the number of observations is reduced dramatically. This results in generally lower t-statistics. School enrollment and the rule of law no longer influence growth significantly. The globalization index, however, is significant at the five percent level.

In recent years, political and institutional variables have been found to have an impact on growth. ${ }^{10}$ Sala-i-Martin (1997) reports a positive influence of civil liberties and political rights on growth. Another variable frequently included in growth regressions is an index of democracy (e.g. Fernandez, Ley and Steel 2001, Sala-i-Martin 1997). Column 4 tests for these impacts. It includes the political rights and civil liberties index constructed by Gastil (2002) and the Polity-IV-indicator of democracy. However, none of these variables has a significant influence on economic growth. Again, the globalization index keeps its significance.

\footnotetext{
${ }^{10}$ Carmignani (2001) provides an overview.
} 
With some of the variables there is an obvious endogeneity problem: previous research has shown, that, e.g., fertility is influenced by measures of wealth (Barro and Lee 1994). If fertility declines with growth, it is endogenous. The same is true for government consumption and investment. Endogeneity might even be a problem for the index of globalization. In the framework of the Arellano-Bond estimation discussed below, the right-hand side variables can be instrumented and the validity of the exogeneity assumption can be tested. ${ }^{11}$ The Arellano-Bond estimator consists in first-differencing the estimating equation and using lags of the dependent variable from at least two periods earlier as well as lags of the right-hand side variables as instruments. Since there are more instruments than right-hand side variables, the equations are over-identified and instruments must be weighted in an appropriate way.

I now regress the natural logarithm of per capita GDP at the end of a five-year period on its lag and other variables, as opposed to regressing the growth rate on these variables. However, the formulation of the model in differences means that the regression shows how changes in globalization affect growth.

Column 5 presents results from the Arellano-Bond one-step GMM estimator, which uses the identity matrix as a weighting matrix. ${ }^{12}$ Applying this estimator leads to a dramatic loss of observations, since information from two periods is discarded by differencing and instrumenting. In some cases, this results in lower t-statistics. With one exception, the results are nevertheless similar to those obtained with OLS: GDP per capita at the beginning of the period is now significantly positive. This confirms the results of Dollar and Kraay (2001). The index of globalization is significant at the five percent level, again with a positive sign. Compared to the previous results, the magnitude of the coefficient is similar. The estimate shows that a one point increase in the index of globalization increases GDP growth by seven percentage points. The average yearly growth rate thus equals about 1.4 percentage points, slightly higher than the previous result of 1.09 .

On the basis of the Arellano-Bond estimator, a Sargan test on the validity of the instruments can be conducted. This amounts to a test for the exogeneity of the covariates. As can be seen from column 3, the Sargan test accepts the over-identifying restrictions. Hence, strict exogeneity is not rejected. The Arellano-Bond test of second order autocorrelation, which must not be present in the data in order for the estimator to be consistent, also accepts the specification.

\footnotetext{
${ }^{11}$ Moreover, the GMM estimator of Arellano and Bond (1991) is consistent, whereas the within groups estimator is inconsistent in the presence of a lagged dependent variable in a short panel (Nickell 1981).

${ }^{12}$ The two-step GMM estimator weighs the instruments asymptotically efficiently using the GMM1 estimates. However, in small samples like this, standard errors tend to be under-estimated by the two-step estimator (Arellano and Bond 1991: 291).
} 
While the overall effect of globalization on growth was found to be positive, it is interesting to examine the effects of the single components. It is not obvious that economic, cultural and political dimensions of globalization will necessarily go along with or reinforce each other (Brown et al. 2000: 280). As column 6 shows, only economic integration seems to be correlated with growth rates. Neither social nor political integration seem to have any influence on economic growth. One potential problem with this specification results from the high correlation between the three sub-indexes. ${ }^{13}$ This probably results in lower t-statistics. Therefore, the three dimensions of globalization are analyzed individually as well. In an effort to provide more detailed information, I replicate the analysis with the sub-indexes instead of the overall index of globalization. Table 5 starts with economic integration. There are various reasons why economic integration should promote growth. Trade makes it possible to exploit comparative advantages. Countries gain from specialization. Foreign investment might serve to close "idea gaps" between developing and developed countries (Romer 1993). It often comes along with management educated in industrial countries. This management may try to press for reforms, in order to improve the business environment and enhance profits (Boockmann and Dreher 2003). Since there might be spillover effects, foreign investment could increase the productivity of the whole economy (Rappaport 2000). Workers from other countries probably produce similar effects. Openness to international trade should promote growth since it encourages gains from trade and fosters innovation and efficient production. The effects of capital controls on growth are less obvious a priori. With open capital accounts, countries in need of capital can borrow abroad to finance investment, which promotes growth (Obstfeld 1998: 2). Moreover, government interventions probably result in inefficiencies and underinvestment. They could also promote corruption. ${ }^{14}$ On the other hand, however, such controls can ensure that domestic savings are channelled towards domestic investment (Chanda 2001: 5). In some cases, capital controls increase the flexibility of monetary and fiscal policy. This could increase domestic growth rates.

Column 1 shows the results for the economic integration subindex (estimated by OLS). As can be seen, higher economic integration is significantly associated with higher growth. However, while actual flows promote growth rates (column 2), restrictions on trade and capital do not have any influence (column 3).

The insignificant coefficient of restrictions could reflect an average of the benefits from liberalization in countries with highly developed financial markets and institutions and

\footnotetext{
13 The correlation between economic integration and social globalization is 0.51 , those between economic integration and political engagement 0.11 and those between social globalization and political engagement 0.47 .
} 
the costs associated with a higher frequency of financial crisis in less developed countries. According to the World Bank (2002: 10), integration with global capital markets can lead to disastrous results without sound domestic financial systems. Garrett (2001) suggests that capital account openness promotes growth only in more developed countries. I therefore employ interactions of the restrictions-subindex with dummies for low, middle and high levels of GDP and the log of these countries' per capita GDP at the beginning of a five-year period. The results are reported in column 4. It turns out that freedom from restrictions significantly promotes growth only in high income countries. In low and middle income countries, the coefficients of the interactions are insignificant. ${ }^{15}$ The insignificant coefficient does, however, not necessarily mean that liberalization does have no influence on growth in these countries. Even in the absence of a direct effect, lower tariffs probably lead to more trade, and liberalization of the capital account promotes foreign investment. Therefore, the absence of restrictions could increase growth rates nevertheless.

Columns 5 to 7 report results estimated with the Arellano-Bond estimator. Confirming the OLS results, the overall sub-index, the index of actual flows and the interaction of high income and restrictions significantly influence growth. However, the Sargan test rejects the instruments when the interactions are included. I therefore treat them as predetermined. Column $7 \mathrm{~b}$ shows the results. The coefficient of the high income and restrictions interaction term is highly significant. Both the Sargan test and the Arellano-Bond test of second-order autocorrelation now clearly accept the specification.

Table 6 reports the results for the political dimension. This aspect of globalization has never been studied in the context of growth. However, political integration might influence growth rates. Economic globalization leads to the inability of national governments to control their citizens (Allison 2000: 83). On the one hand, high political integration could serve governments as counterweight to globalized markets. They could cooperate to promote more redistribution than would otherwise be possible. This would probably reduce economic growth. A good example is pre-industrial-revolution-Europe. Low political integration and resulting competition between governments strongly promoted economic and technical innovations (Rosenberg and Birdzell 1986: 137, Jones 1981: 138). On the other hand, high integration could lead to reforms in political or economic processes and thus promote growth. Examples could be monopoly regulation in the European Union or free trade zones like

\footnotetext{
${ }^{14}$ It has been shown by Dreher and Siemers (2003) that capital account restrictions and corruption re-enforce each other.

${ }^{15}$ To analyze this relationship in more detail, I also interacted the index with the measures of financial markets' quality introduced above and with the rule of law index. All resulting coefficients are, however, completely insignificant. This is consistent with Rodrik (1998).
} 
NAFTA and MERCOSUR. As columns 1 and 2 show, however, political integration is completely irrelevant for economic growth.

Finally, Table 7 reports results for social integration. As Boockmann and Dreher (2003) point out, means of information and communication may prove important since they relay information about economic success in other countries. Exposure to such information may provoke discussions which result in the acceptance of new concepts (Brown et al. 2000: 279). Successful technologies are then adopted which promotes growth. As MayerSchöenberger and Hurley (2000: 147) put it, global communication networks promote international trade and economic integration, as they lower cross-border transaction costs. Marketing information can thus be accessed by customers worldwide which implicates a decline in the importance of geographic proximity. Given a certain level of information about economic policies in other countries, cultural proximity could reduce resistance against those ideas. For example, structural reforms conducted by many industrial countries in the eighties spread only slowly to developing nations. Only with increased proximity, developing countries reformed their economies as well. It could also be, that simply adopting Western technology would not lead to higher growth rates without adopting the social and cultural environment in which it is embedded (Saich 2000: 211).

Since data on cultural proximity are available for only two periods, the Table includes only results on personal contact and information flows as well as the overall sub-index. As can be seen in column 1, social integration significantly promotes growth. The index of personal contact is only marginally significant, information flows are significant at the one percent level (columns 2 and 3, respectively).

When estimated with GMM (and thus in differences), all three indexes do not seem to influence growth (columns 4 to 6). The former results may thus emerge due to reversed causality. I therefore tried to estimate all regressions with the globalization variables lagged one five-year-period (not reported in the Table). It turns out that only information flows have a significant influence on economic growth. This result is confirmed, when I treat information flows as predetermined in the GMM regression (column 6b). ${ }^{16}$ Only this specification is accepted by the Sargan test and the Arellano-Bond test, while the overidentifying restrictions are rejected when the index is treated as exogenous.

Summing up, in addition to the overall index of globalization, several dimensions have a significant (positive) influence on growth: actual economic flows, capital and trade

\footnotetext{
${ }^{16}$ When treated as predetermined, the overall social integration index is also significant at the one percent level.
} 
restrictions in developed countries, and flows of information. The following paragraph examines the robustness of these findings.

\section{Robustness Analysis}

I test for the robustness of the overall index, actual economic flows, capital and trade restrictions in developed countries, and flows of information. First, I check for the influence of outliers using an algorithm that is robust to them. The algorithm minimizes the median (rather than the mean) of the residuals. ${ }^{17}$ Second, I replicate all regressions (estimated with OLS and GMM) omitting the following sub-groups: East Asian countries, Latin American countries, Sub-Saharan-African countries, OECD countries and, finally, India and China. Third, I include further variables which could influence the relationship between the indexes and growth: black market premium, overall budget balance, political instability, the theil index of inequality ${ }^{18}$ as well as the variables of banking quality and institutional variables introduced above.

As an obvious shortcoming of the procedure used to derive the globalization indexes, changes in the index over time might to some extent reflect missing data instead of real changes in globalization. To examine this shortcoming, fourth, an alternative procedure has been used as well: In those years where no data for some categories exist, the latest data available have been employed for constructing the indexes. Changes in the index over time therefore only reflect changes in the underlying data.

To measure political instability, I construct an index employing the following variables: assassinations, strikes, guerrilla warfare, crisis, riots and revolutions. Since those variables are highly collinear, they can not all be included separately in one regression. Therefore an overall indicator is constructed, again using principal components analysis. ${ }^{19}$

Table 8 shows the results of the stability analysis. It turns out that the overall index of globalization is not completely robust to the inclusion of further variables in the GMM regressions. In most cases, however, the coefficients do not become insignificant because of the inclusion of the variables but to the drastically reduced number of observations. For example, including the variables of banking quality, reduces the number of observations to 183 (when estimated with GMM). The coefficients remain insignificant when the sample is

\footnotetext{
${ }^{17}$ Least absolute value $=\min _{\mathrm{b}} \underset{i}{\text { median }}\left|y_{i}-x_{i} b\right|$.

${ }^{18} \mathrm{I}$ also tried the gini coefficient but this leaves us with too few observations for a meaningful regression.

${ }^{19}$ The weights obtained are 0.08 (assassination), 0.1 (strikes), 0.25 (guerrilla warfare), 0.15 (crisis), 0.16 (riots) and 0.27 (revolutions).
} 
restricted to those countries where the additional variables are available even if the variables are not included in the regression.

Actual economic flows are highly robust to the inclusion of further variables, the exclusion of countries, the estimation method, and the construction of the index. Its coefficient is significant at least at the ten percent level in all regressions. The influence of restrictions in developed countries is similarly robust. Only the reduction in the number of observations when the banking quality variables are included destroys its significant influence on growth. If the banking quality variables are included, only 194 observations remain. I do not exclude OECD countries since this would leave us with an insufficient number of high income countries.

As can be seen in the table, information flows are less robustly related to economic growth. They loose their significance, when any of the additional variables except those accounting for institutional quality are included. Excluding OECD countries also destroys the coefficients' significance. Like the other indexes its is, however, highly robust to the construction of the index.

\section{Conclusion}

It has been shown, that, contrary to the beliefs of its critics, globalization indeed promotes growth. The overall index of globalization is highly significant in most specifications and has been shown to be quite robust to the inclusion of potentially relevant covariates in the regression as well as different estimation methods. These effects are economically relevant. As an example, it has been shown that Latvia could increase its economic growth rate from 5.94 to 7.1 if it would be as integrated with the rest of the world as Spain is. This example shows the limitations of the globalization process in reducing poverty as well. For Latvia to become as globalized as Spain would require enormous efforts. Such effort is nearly impossible to achieve in the short run but will take many years. As another example, the country with the biggest (positive) change in globalization from 1975 to 2000 has been China. Its index increased by 2.14 points. According to the regression results from Table 4 this would mean that China's growth rate in 2000 is 2.33 percentage points higher as in 1975 due to increased integration with the rest of the world.

In summary, globalization is good for growth. On average, countries that globalized more, experienced higher growth rates. This is especially true for actual economic integration and - in developed countries - the absence of restrictions on trade and capital. There is 
although evidence, that cross border information flows promote growth. The accusation that poverty prevails because of globalization is therefore not valid. To the contrary, those countries with the lowest growth rates are those who did not globalize. Countries like Rwanda or Zimbabwe, e.g., insulated themselves from the world economy. They have poor institutions which repress growth and promote poverty. Nevertheless, all else equal it will not be enough for poor countries simply to globalize their economies to spur growth rates and reduce poverty. 


\section{References}

A.T. Kearney/Foreign Policy Magazine (2002), Globalization Index, http://www. foreignpolicy.com.

Alesina, Alberto; Vittorio Grilli and Gian M. Milesi-Ferretti (1994), "The Political Economy of Capital Controls", in: Leonardo Leiderman and Assaf Razin (eds.), Capital Mobility: The Impact on Consumption, Investment and Growth, Cambridge University Press, Cambridge: 289-321.

Allison, Graham (2000), "The Impact of Globalization on National and International Security”, in: Joseph S. Nye and John D. Donahue (eds.), Governance in a Globalizing World, Brookings Institution Press, Washington, D.C.: 72-85.

Arellano, Manuel; Stephen Bond (1991), Some Tests of Specification for Panel Data: Monte Carlo Evidence and an Application to Employment Equations, Review of Economic Studies 58, 277-297.

Barro, Robert J. (1997), Determinants of Economic Growth, A Cross-Country Empirical Study, The MIT Press, Cambridge, Massachusetts.

Barro, Robert J.; Jong-Wha Lee (1994), “Sources of Economic Growth”, Carnegie-Rochester Conference Series on Public Policy: 1-46.

Beck, Thorsten; Asli Demirgüç-Kunt; Ross Levine (1999), A New Database on Financial Development and Structure, Domestic Finance Working Paper 2146, World Bank, Washington, D.C.

Beer, Linda; Terry Boswell (2001), The Effects of Globalization on Inequality: A CrossNational Analysis, Halle Institut Occasional Paper.

Blomström, Magnus; Robert E. Lipsey; Mario Zejan (1992), What Explains Developing Country Growth?, NBER Working Paper 4132.

Boockmann, Bernhard; Axel Dreher (2003), The Contribution of the IMF and the World Bank to Economic Freedom, European Journal of Political Economy, 19, 3: 633-649.

Borensztein, E.; J. de Gregorio; J.-W. Lee. (1998), "How Does Foreign Direct Investment Affect Economic Growth?“, Journal of International Economics 45: 115-135.

Brown, L. David; Sanjeev Khagram; Mark H. Moore; Peter Frumkin (2000), "Globalization, NGOs, and Multisectoral Relations”, in: Joseph S. Nye and John D. Donahue (eds.), Governance in a Globalizing World, Brookings Institution Press, Washington, D.C.: 271-296. 
Brune, Nancy (2000), The Political Economy of Capital Account Liberalization, Working Paper, Midwest Political Science Association Annual Conference.

Carkovic, Maria; Ross Levine (2002), Does Foreign Direct Investment Accelerate Growth?, mimeo, University of Minnesota.

Carmignani, Fabrizio (2001), Theory and Evidence on the Political Economy of Growth, Dipartimento di Economia Politica Working Paper 33, Università degli Studi di Milano-Bicocca.

Chanda, Areendam (2001), The Influence of Capital Controls on Long Run Growth: Where and How Much?, North Carolina State University, mimeo.

Clark, William C. (2000), "Environmental Globalization”, in: Joseph S. Nye and John D. Donahue (eds.), Governance in a Globalizing World, Brookings Institution Press, Washington, D.C.: 86-108.

Dollar, David; Aart Kraay (2001), Trade, Growth, and Poverty, World Bank Discussion Paper, Washington, D.C.

Dollar, David (1992), “Outward-Oriented Developing Economies Really Do Grow More Rapidly: Evidence from 95 LDCs, 1976-85", Economic Development and Cultural Change: 523-544.

Dreher, Axel (2005), "The Influence of Globalization on Taxes and Social Policy - an Empirical Analysis for OECD Countries", European Journal of Political Economy, forthcoming.

Dreher, Axel; Lars-H.R. Siemers (2003), The Intriguing Nexus Between Corruption and Capital Account Restrictions, mimeo, Mannheim and Heidelberg.

Durham, J. Benson (2000), A Survey of the Econometric Literature on the Real Effects of International Capital Flows in Lower Income Countries, QEH Working Paper 50, mimeo, University of Oxford.

Edison, Hali J.; Michael Klein; Luca Ricci; Torsten Sløk (2002), Capital Account Liberalization and Economic Performance: Survey and Synthesis, IMF Working Paper 02/120, Washington, D.C.

Edison, Hali J.; Ross Levine; Luca Ricci; Torsten Sløk (2002a), International Financial Integration and Economic Growth, IMF Working Paper 02/145, Washington, D.C.

Europa World Yearbook (various years), Europa Publications, London, UK.

Fernandez, Carmen; Eduardo Ley; Mark Steel (2001), "Model uncertainty in cross-country growth regressions", Journal of Applied Econometrics, forthcoming. 
Frankel, Jeffrey A.; David Romer (1996), Trade and Growth: An Empirical Investigation, NBER Working Paper 5476.

Garrett, Geoffrey (2001), The Distributive Consequences of Globalization, UCLA, MS.

Gastil, Raymond (2002), Freedom in the World 2001-2002, Freedomhouse, http://www.freedomhouse.org.

Global Development Network Growth Database, World Bank, http://econ.worldbank.org/.

Greenaway, David; Wyn Morgan; Peter Wright (1999), Exports, Export Composition and Growth, Journal of International Trade \& Economic Development 8, 1: 41-51.

Gwartney, James; Robert Lawson (2002, 2001), Economic Freedom of the World: Annual Report, http://www.freetheworld.org/.

Hansson, Åsa (2000), “Government Size and Growth: An Empirical Study of 21 OECD Countries", in: Åsa Hansson, Limits of Tax Policy, Lund Economics Studies number 90: Chapter 4.

Heinemann, Friedrich (2000), Does Globalization Restrict Budgetary Autonomy? A Multidimensional Approach, Intereconomics 35, 6: 288-298.

International Monetary Fund (2002), International Financial Statistics Indicators, CD-Rom. International Monetary Fund (1998), Exchange Arrangements and Exchange Restrictions, Annual Report, Washington, D.C.

International Telecommunications Union (various years), Yearbook of Statistics, Geneva.

Jones, Eric L. (1981), The European Miracle, Cambridge.

Keohane, Robert O; Joseph S. Nye (2000), “Introduction”, in: Joseph S. Nye and John D. Donahue (eds.), Governance in a Globalizing World, Brookings Institution Press, Washington, D.C.: 1-44.

King, Robert G.; Ross Levine (1993), Finance and Growth: Schumpeter Might be Right, The Quarterly Journal of Economics 108, 3: 717-737.

Li, Quan; Rafael Reuveny (2003), Economic Globalization and Democracy: An Empirical Analysis, British Journal of Political Science, forthcoming.

Lockwood, Ben (2004), How Robust is the Kearney/ Foreign Policy Globalisation Index? The World Economy 27, 4: 507-523.

Marshall, Monty G.; Keith Jaggers (2000), Polity IV Project: Political Regime Characteristics and Transitions, 1800-2000, http://www.cidem.umd.edu/inscr/polity/.

Mayer-Schöenberger, Viktor; Deborah Hurley (2000), “Globalization of Communication”, in: Joseph S. Nye and John D. Donahue (eds.), Governance in a Globalizing World, Brookings Institution Press, Washington, D.C.: 135-154. 
Nickell, S. J. (1981), Biases in Dynamic Models with Fixed Effects, Econometrica, 49: 14171426.

Norris, Pippa (2000), “Global Governance and Cosmopolitan Citizens”, in: Joseph S. Nye and John D. Donahue (eds.), Governance in a Globalizing World, Brookings Institution Press, Washington, D.C.: 155-177.

Obstfeld, Maurice (1998), The Global Capital Market: Benefactor or Menace?, NBER Working Paper 6559, Cambridge, MA.

Rappaport, Jordan (2000), How Does Openness to Capital Flows Affect Growth?, Federal Reserve Bank of Kansas City, mimeo.

Rodrik, Dani (1998), “Who Needs Capital Account Convertibility?”, in: Stanley Fischer et al. (eds.), Should the IMF Pursue Capital Account Convertibility?, Essays in International Finance 207, Department of Economics, Princeton University, Princeton, NJ: 55-65.

Romer, Paul (1993), Idea Gaps and Object Gaps in Economic Development, Journal of Monetary Economics 32, 3: 543-573.

Rosenberg, Nathan; Leon E. Birdzell, Jr. (1986), How the West Grew Rich, New York.

Rosendorf, Neal M. (2000), "Social and Cultural Globalization: Concepts, History, and America's Role", in: Joseph S. Nye and John D. Donahue (eds.), Governance in a Globalizing World, Brookings Institution Press, Washington, D.C.: 109-134.

Saich, Tony (2000), "Globalization, Governance, and the Authoritarian State: China”, in: Joseph S. Nye and John D. Donahue (eds.), Governance in a Globalizing World, Brookings Institution Press, Washington, D.C.: 208-228.

Sala-i-Martin, Xavier (1997), I Just Ran Four Million Regressions, NBER Working Paper 6252.

Union of International Associations (various years), Yearbook of International Organizations, Vol. 2.

University of Texas Inequality Project, University of Texas at Austin, http://utip.gov.utexas .edu/web/world_theils.htm.

Vaubel, Roland (1999), "Internationaler Politischer Wettbewerb: Eine europäische Wettbewerbsaufsicht für Regierungen und die empirische Evidenz", in: Karl-Ernst Schenk, Dieter Schmidtchen, Manfred E. Streit, Viktor Vanberg (eds.), Jahrbuch für Neue Politische Ökonomie: 280-309.

World Bank (2002), Globalization, Growth, and Poverty: Building an Inclusive World Economy, Policy Research Report, Oxford University Press.

World Bank (2002a), World Development Indicators, CD-Rom. 
Table 1: Components of Index of Globalization

\begin{tabular}{|c|c|c|}
\hline A. & Data on Economic Integration & {$[35 \%]$} \\
\hline & i) Actual Flows & $(50 \%)$ \\
\hline & Trade (in percent of GDP)* & $(23 \%)$ \\
\hline & Foreign Direct Investment (in percent of GDP)* & $(29 \%)$ \\
\hline & Portfolio Investment (in percent of GDP)* & $(27 \%)$ \\
\hline & Income payments to foreign nationals (in percent of GDP)* & $(22 \%)$ \\
\hline & ii) Restrictions & $(50 \%)$ \\
\hline & Hidden Import Barriers & $(20 \%)$ \\
\hline & Mean Tariff Rate & $(30 \%)$ \\
\hline & Taxes on International Trade (in percent of current revenue) & $(24 \%)$ \\
\hline & Capital Account Restrictions & $(26 \%)$ \\
\hline B. & Data on Political Engagement & [28\%] \\
\hline & Embassies in Country* & $(34 \%)$ \\
\hline & Membership in International Organizations* & $(34 \%)$ \\
\hline & Participation in UN Security Council Missions* & $(32 \%)$ \\
\hline C. & Data on Social Globalization & [38\%] \\
\hline & i) Data on Personal Contact & $(24 \%)$ \\
\hline & Outgoing telephone traffic* & $(31 \%)$ \\
\hline & Transfers (in percent of GDP)* & $(9 \%)$ \\
\hline & International Tourism* & $(1 \%)$ \\
\hline & Telephone Average Costs of Call to USA & $(33 \%)$ \\
\hline & Foreign Population (in percent of total population) & $(26 \%)$ \\
\hline & ii) Data on Information Flows & $(39 \%)$ \\
\hline & Telephone Mainlines (per 1000 people) & $(18 \%)$ \\
\hline & Internet Hosts (per capita)* & $(15 \%)$ \\
\hline & Internet Users (as a share of population)* & $(18 \%)$ \\
\hline & Cable Television (per 1000 people) & $(16 \%)$ \\
\hline & Daily Newspapers (per 1000 people) & $(16 \%)$ \\
\hline & Radios (per 1000 people) & $(17 \%)$ \\
\hline & iii) Data on Cultural Proximity & $(37 \%)$ \\
\hline & Number of McDonald's Restaurants (per capita) & $(100 \%)$ \\
\hline
\end{tabular}

Notes: The number in parenthesis indicates the weight used to derive the indexes. Weights may not sum to 100 because of rounding. All indexes range between 0 (not globalized) and 10 (globalized).

*: These variables have been used in the AT.Kearney/Foreign Policy Index as well. 
Table 2: Ratings of Globalization

\begin{tabular}{|c|c|c|c|c|c|c|c|}
\hline & & Economic & Social & Political & & Ratin & \\
\hline & Country Name & 2000 & 2000 & 2000 & 1975 & 1990 & 2000 \\
\hline 1. & United States & 4.92 & 6.90 & 7.88 & 4.56 & 3.76 & 6.48 \\
\hline 2. & Canada & 5.17 & 6.56 & 7.61 & 5.49 & 4.78 & 6.37 \\
\hline 3. & Sweden & 5.62 & 5.63 & 7.85 & 5.18 & 5.11 & 6.24 \\
\hline 4. & Denmark & 5.63 & 4.76 & 7.26 & 5.28 & 4.45 & 5.75 \\
\hline 5. & Finland & 5.67 & 5.00 & 6.79 & 4.32 & 4.51 & 5.73 \\
\hline 6. & Luxembourg & 8.84 & 5.37 & 2.21 & 5.45 & 5.42 & 5.71 \\
\hline 7. & United Kingdom & 6.01 & 4.21 & 7.04 & 5.04 & 4.24 & 5.62 \\
\hline 8. & Switzerland & 5.96 & 5.16 & 5.63 & 4.86 & 5.04 & 5.57 \\
\hline 9. & France & 5.19 & 3.47 & 8.58 & 4.24 & 3.73 & 5.48 \\
\hline 10. & Belgium & 6.18 & 3.44 & 7.33 & 6.30 & 4.95 & 5.47 \\
\hline 11. & Norway & 5.31 & 4.68 & 6.62 & 4.37 & 4.39 & 5.43 \\
\hline 12. & Netherlands & 6.46 & 4.21 & 5.52 & 5.31 & 4.29 & 5.36 \\
\hline 13. & Germany & 5.38 & 3.94 & 6.99 & 4.26 & 3.74 & 5.28 \\
\hline 14. & Austria & 5.39 & 4.00 & 6.75 & 4.44 & 4.41 & 5.25 \\
\hline 15. & Ireland & 6.75 & 3.74 & 4.92 & 3.59 & 4.19 & 5.12 \\
\hline 16. & Australia & 4.60 & 6.05 & 4.37 & 3.58 & 3.98 & 5.08 \\
\hline 17. & Singapore & 6.90 & 5.35 & 2.11 & 3.56 & 3.95 & 5.00 \\
\hline 18. & New Zealand & 5.30 & 5.79 & 3.35 & 3.31 & 3.46 & 4.95 \\
\hline 19. & United Arab Emirates & 8.15 & 3.36 & 2.54 & 3.41 & 2.70 & 4.81 \\
\hline 20. & Hong Kong & 7.31 & 5.92 & 0.00 & 4.20 & 4.10 & 4.78 \\
\hline 21. & Japan & 4.16 & 4.93 & 4.84 & 3.92 & 3.29 & 4.64 \\
\hline 22. & Italy & 5.11 & 2.22 & 7.05 & 4.14 & 3.65 & 4.56 \\
\hline 23. & Portugal & 5.61 & 2.51 & 4.88 & 2.23 & 2.52 & 4.25 \\
\hline 24. & Spain & 5.01 & 2.22 & 5.31 & 2.85 & 2.91 & 4.05 \\
\hline 25. & Iceland & 4.87 & 4.53 & 2.05 & 3.49 & 3.12 & 3.97 \\
\hline 26. & Argentina & 4.17 & 1.98 & 5.96 & 2.35 & 2.61 & 3.84 \\
\hline 27. & Czech Republic & 4.86 & 2.32 & 4.48 & n.a. & n.a. & 3.80 \\
\hline 28. & Poland & 3.65 & 2.08 & 6.30 & 2.77 & 2.72 & 3.79 \\
\hline 29. & Israel & 4.73 & 3.77 & 2.51 & 3.10 & 2.40 & 3.76 \\
\hline 30. & Russian Federation/ USSR & 3.29 & 1.41 & 7.50 & 1.07 & 0.92 & 3.74 \\
\hline 31. & Greece & 4.76 & 2.36 & 4.30 & 3.01 & 2.60 & 3.73 \\
\hline 32. & Uruguay & 4.43 & 2.66 & 3.99 & 3.55 & 2.59 & 3.65 \\
\hline 33. & Kuwait & 4.31 & 3.60 & 2.72 & 2.72 & 2.77 & 3.61 \\
\hline 34. & Malta & 4.68 & 4.19 & 1.34 & 2.93 & 2.18 & 3.57 \\
\hline 35. & Malaysia & 4.69 & 2.02 & 4.16 & 2.50 & 2.41 & 3.54 \\
\hline 36. & Hungary & 4.26 & 2.41 & 4.16 & 2.77 & 2.41 & 3.54 \\
\hline 37. & Egypt & 3.41 & 1.32 & 6.67 & 1.59 & 1.71 & 3.52 \\
\hline 38. & Bahrain & 5.50 & 2.79 & 1.77 & 2.62 & 2.83 & 3.46 \\
\hline 39. & Estonia & 5.81 & 2.68 & 1.44 & n.a. & n.a. & 3.43 \\
\hline 40. & Korea, Republic & 3.86 & 2.72 & 3.65 & 2.71 & 2.85 & 3.37 \\
\hline 41. & Chile & 4.45 & 1.84 & 3.66 & 2.44 & 2.54 & 3.25 \\
\hline 42. & Turkey & 4.04 & 1.65 & 4.22 & 1.85 & 1.72 & 3.19 \\
\hline 43. & Venezuela & 4.10 & 1.73 & 3.99 & 2.86 & 2.24 & 3.18 \\
\hline 44. & Brazil & 3.50 & 1.54 & 4.95 & 1.51 & 1.56 & 3.17 \\
\hline 45. & Cyprus & 3.32 & 3.79 & 2.04 & 2.03 & 2.28 & 3.15 \\
\hline 46. & Jordan & 3.93 & 1.00 & 5.07 & 1.59 & 1.66 & 3.15 \\
\hline 47. & Panama & 4.90 & 2.09 & 2.31 & 3.81 & 2.74 & 3.13 \\
\hline 48. & Slovak Republic & 4.48 & 2.04 & 2.80 & n.a. & n.a. & 3.10 \\
\hline 49. & Costa Rica & 4.74 & 2.06 & 2.39 & 2.34 & 2.13 & 3.09 \\
\hline 50. & Indonesia & 3.85 & 0.96 & 4.98 & 1.69 & 1.73 & 3.08 \\
\hline 51. & Slovenia & 4.31 & 2.84 & 1.79 & n.a. & n.a. & 3.07 \\
\hline
\end{tabular}


Table 2 (continued)

\begin{tabular}{|c|c|c|c|c|c|c|c|}
\hline & & Economic & Social & Political & & y Rati & \\
\hline & Country Name & 2000 & 2000 & 2000 & 1975 & 1990 & 2000 \\
\hline 52. & China & 3.23 & 1.17 & 5.36 & 0.90 & 1.60 & 3.04 \\
\hline 53. & Romania & 3.73 & 1.62 & 4.08 & 3.34 & 1.84 & 3.04 \\
\hline 54. & South Africa & 4.21 & 1.56 & 3.55 & 1.96 & 1.68 & 3.03 \\
\hline 55. & Latvia & 4.94 & 2.25 & 1.54 & n.a. & n.a. & 2.99 \\
\hline 56. & Mexico & 4.03 & 1.47 & 3.44 & 2.19 & 2.13 & 2.91 \\
\hline 57. & Trinidad and Tobago & 4.57 & 1.94 & 1.92 & 1.92 & 1.75 & 2.86 \\
\hline 58. & Bulgaria & 4.04 & 1.25 & 3.43 & 2.72 & 2.45 & 2.83 \\
\hline 59. & Kenya & 3.33 & 0.81 & 4.81 & 1.70 & 1.38 & 2.80 \\
\hline 60. & Jamaica & 4.21 & 2.11 & 1.88 & 2.10 & 1.89 & 2.78 \\
\hline 61. & Zambia & 4.62 & 1.19 & 2.63 & 2.15 & 1.73 & 2.78 \\
\hline 62. & India & 2.26 & 1.01 & 5.86 & 1.85 & 1.55 & 2.78 \\
\hline 63. & Lithuania & 4.66 & 1.79 & 1.74 & n.a. & n.a. & 2.78 \\
\hline 64. & Bolivia & 4.32 & 1.10 & 2.88 & 2.04 & 1.89 & 2.72 \\
\hline 65. & Peru & 4.22 & 1.11 & 2.87 & 2.00 & 1.62 & 2.68 \\
\hline 66. & Nicaragua & 4.66 & 1.18 & 2.17 & 2.21 & 1.61 & 2.67 \\
\hline 67. & Thailand & 3.40 & 1.21 & 3.61 & 1.62 & 1.41 & 2.64 \\
\hline 68. & El Salvador & 4.39 & 1.57 & 1.84 & 1.84 & 1.57 & 2.63 \\
\hline 69. & Tunisia & 2.48 & 1.09 & 4.91 & 1.97 & 1.86 & 2.63 \\
\hline 70. & Colombia & 3.61 & 1.39 & 3.03 & 1.71 & 1.54 & 2.62 \\
\hline 71. & Senegal & 3.00 & 1.02 & 4.23 & 1.57 & 1.15 & 2.60 \\
\hline 72. & Bangladesh & 2.56 & 1.03 & 4.76 & 1.08 & 1.31 & 2.59 \\
\hline 73. & Ghana & 2.78 & 1.40 & 3.94 & 1.57 & 1.97 & 2.58 \\
\hline 74. & Fiji & 3.93 & 1.73 & 1.95 & 1.89 & 2.38 & 2.56 \\
\hline 75. & Ukraine & 3.77 & 0.74 & 3.46 & n.a. & n.a. & 2.55 \\
\hline 76. & Nigeria & 2.72 & 0.16 & 5.51 & 1.84 & 1.87 & 2.53 \\
\hline 77. & Algeria & 2.81 & 1.21 & 3.93 & 1.81 & 1.48 & 2.52 \\
\hline 78. & Guatemala & 3.89 & 1.45 & 2.06 & 1.85 & 1.53 & 2.47 \\
\hline 79. & Philippines & 3.60 & 1.16 & 2.82 & 1.41 & 1.45 & 2.47 \\
\hline 80. & Ecuador & 3.65 & 1.19 & 2.60 & 1.81 & 1.64 & 2.44 \\
\hline 81. & Pakistan & 1.58 & 1.12 & 5.30 & 1.54 & 0.99 & 2.43 \\
\hline 82. & Morocco & 2.48 & 1.14 & 4.09 & 1.92 & 1.82 & 2.42 \\
\hline 83. & Mauritius & 3.89 & 1.70 & 1.46 & 1.77 & 1.41 & 2.40 \\
\hline 84. & Oman & 4.29 & 0.78 & 2.15 & 2.58 & 2.05 & 2.38 \\
\hline 85. & Uganda & 4.14 & 0.89 & 1.91 & 1.24 & 0.79 & 2.31 \\
\hline 86. & Honduras & 3.85 & 1.20 & 1.84 & 1.65 & 1.39 & 2.30 \\
\hline 87. & Croatia & 2.89 & 1.99 & 1.86 & n.a. & n.a. & 2.27 \\
\hline 88. & Botswana & 4.36 & 1.13 & 1.10 & 2.68 & 2.29 & 2.25 \\
\hline 89. & Zimbabwe & 3.14 & 1.14 & 2.52 & 0.70 & 1.56 & 2.22 \\
\hline 90. & Dominican Republic & 3.04 & 1.51 & 1.95 & 1.58 & 1.38 & 2.17 \\
\hline 91. & Sri Lanka & 3.10 & 1.10 & 2.16 & 1.08 & 1.31 & 2.09 \\
\hline 92. & Iran & 2.42 & 1.01 & 3.11 & 2.44 & 1.33 & 2.08 \\
\hline 93. & Cameroon & 2.50 & 0.99 & 3.00 & 1.47 & 1.41 & 2.07 \\
\hline 94. & Cote d'Ivoire & 2.37 & 0.95 & 3.08 & 1.06 & 1.32 & 2.03 \\
\hline 95. & Namibia & 2.99 & 1.22 & 1.77 & 0.21 & 1.56 & 1.99 \\
\hline 96. & Tanzania & 2.09 & 0.97 & 3.18 & 1.99 & 1.18 & 1.97 \\
\hline 97. & Syrian Arab Republic & 3.01 & 0.26 & 2.96 & 1.82 & 1.65 & 1.96 \\
\hline 98. & Albania & 3.00 & 1.17 & 1.71 & 0.85 & 0.27 & 1.96 \\
\hline 99. & Paraguay & 3.45 & 0.63 & 1.83 & 1.76 & 1.72 & 1.94 \\
\hline 100. & Guyana & 3.53 & 0.72 & 1.51 & 1.87 & 1.90 & 1.92 \\
\hline 101. & Bahamas & 1.13 & 3.31 & 0.83 & 0.95 & 1.54 & 1.87 \\
\hline 102. & Saudi Arabia & 0.86 & 1.72 & 3.27 & 2.08 & 1.39 & 1.84 \\
\hline
\end{tabular}


Table 2 (continued)

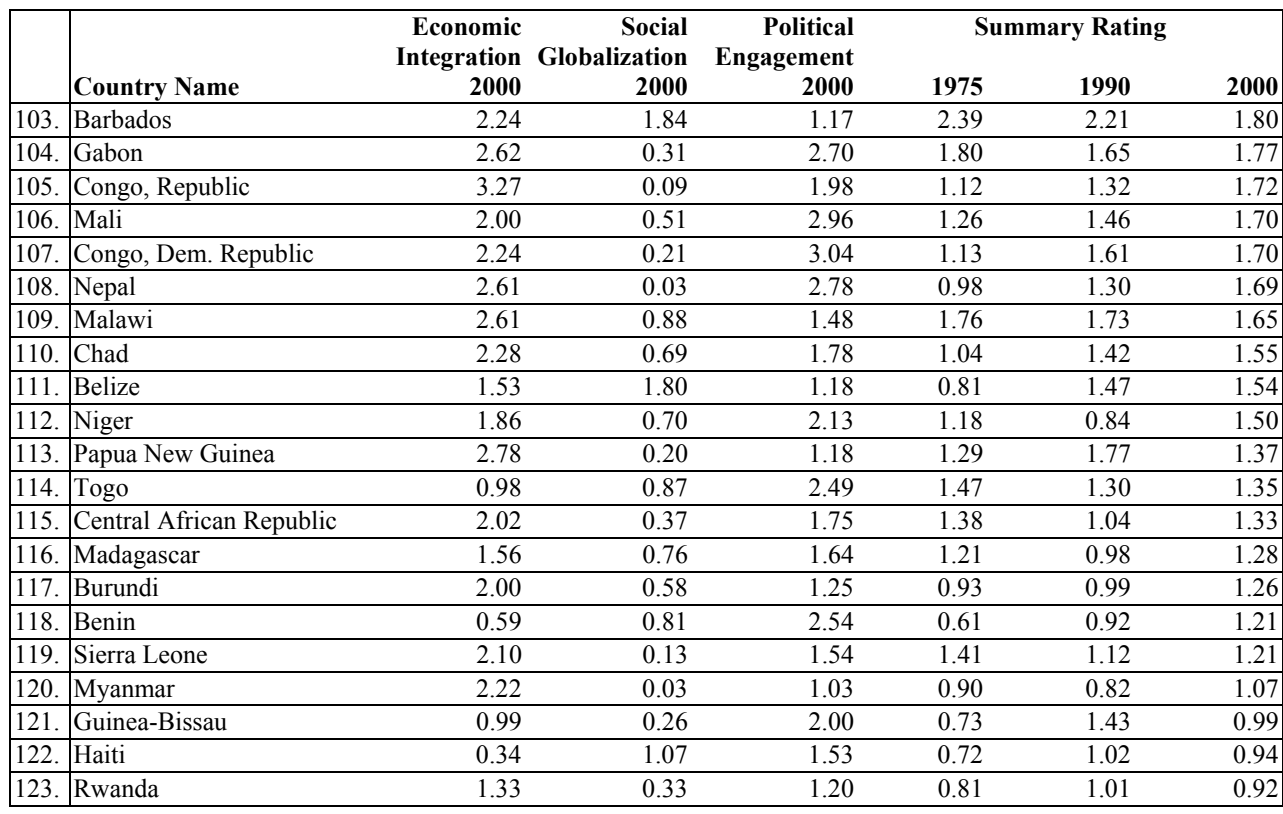

Notes: All indexes range from 0 (not globalized) to 10 (globalized). The countries are ranked according to their overall index score in 2000.

Table 3: Per Capita GDP Growth and Globalization (1970-2000, 123 countries)

\begin{tabular}{|rrrrrrr|}
\hline $\begin{array}{r}\text { Countries With Low } \\
\text { Globalization }\end{array}$ & 2.62 & 2.08 & 0.35 & 0.68 & 0.14 & 1.16 \\
$\begin{array}{r}\text { Number of countries } \\
\text { Countries With High }\end{array}$ & 2.99 & 3.02 & 0.79 & 2.64 & 1.24 & 2.04 \\
$\begin{array}{r}\text { Globalization } \\
\text { Number of countries }\end{array}$ & 38 & 38 & 36 & 36 & 59 & 82 \\
\hline $\begin{array}{r}\mathrm{H}_{0}: \text { mean }(\text { low })- \\
\text { mean(high }=0(\mathrm{P}>|\mathrm{t}|)\end{array}$ & 0.58 & 0.17 & 0.51 & 0.001 & 0.11 & 0.05 \\
\hline
\end{tabular}

Notes: Indicates GDP per capita growth rates in percent in countries with an overall globalization index smaller and greater than the index-mean of 2.45 , respectively. 
Table 4: Per Capita GDP Growth and Globalization (1970-2000)

\begin{tabular}{|c|c|c|c|c|c|c|}
\hline & 1 & 2 & 3 & 4 & 5 & 6 \\
\hline Overall Index of Globalization & & $\begin{array}{r}1.09 \\
\left(3.49^{\circ}\right)\end{array}$ & $\begin{array}{c}0.84 \\
\left(2.29^{*}\right)\end{array}$ & $\begin{array}{l}0.95 \\
\left(2.96^{\circ}\right)\end{array}$ & $\begin{array}{c}0.07 \\
\left(2.29^{*}\right)\end{array}$ & \\
\hline Index of Economic Integration & & & & & & $\begin{array}{c}0.04 \\
\left(2.53^{*}\right)\end{array}$ \\
\hline Index of Social Integration & & & & & & $\begin{array}{c}0.02 \\
(1.06)\end{array}$ \\
\hline Index of Political Integration & & & & & & $\begin{array}{c}0.01 \\
(0.64)\end{array}$ \\
\hline $\begin{array}{l}\text { Log (per capita GDP), } \\
\text { beginning of period }\end{array}$ & $\begin{array}{l}-5.74 \\
\left(-6.86^{\circ}\right)\end{array}$ & $\begin{array}{c}-5.93 \\
\left(-7.30^{\circ}\right)\end{array}$ & $\begin{array}{c}-7.34 \\
\left(-5.39^{\circ}\right)\end{array}$ & $\begin{array}{l}-5.88 \\
\left(-7.33^{\circ}\right)\end{array}$ & $\begin{array}{l}1.30 \\
\left(3.70^{\circ}\right)\end{array}$ & $\begin{array}{c}1.22 \\
\left(3.30^{\circ}\right)\end{array}$ \\
\hline Secondary School Enrollment & $\begin{array}{c}0.03 \\
\left(3.11^{\circ}\right)\end{array}$ & $\begin{array}{c}0.03 \\
\left(2.53^{*}\right)\end{array}$ & $\begin{array}{r}0.004 \\
(0.40)\end{array}$ & $\begin{array}{c}0.03 \\
\left(2.33^{*}\right)\end{array}$ & $\begin{array}{l}-0.003 \\
(-1.32)\end{array}$ & $\begin{array}{l}-0.002 \\
(-0.99)\end{array}$ \\
\hline Log (Life Expectancy) & $\begin{array}{c}1.86 \\
(0.84)\end{array}$ & $\begin{array}{c}0.60 \\
(0.26)\end{array}$ & $\begin{array}{c}3.27 \\
(0.88)\end{array}$ & $\begin{array}{c}-0.04 \\
(-0.02)\end{array}$ & $\begin{array}{c}-0.37 \\
(-1.54)\end{array}$ & $\begin{array}{c}-0.33 \\
(-1.44)\end{array}$ \\
\hline Log (Fertility Rate) & $\begin{array}{l}-1.38 \\
(-1.38)\end{array}$ & $\begin{array}{l}-1.49 \\
(-1.48)\end{array}$ & $\begin{array}{l}-1.04 \\
(-0.86)\end{array}$ & $\begin{array}{l}-1.25 \\
(-1.20)\end{array}$ & $\begin{array}{c}-0.28 \\
\left(-2.36^{*}\right)\end{array}$ & $\begin{array}{c}-0.28 \\
\left(-2.55^{\circ}\right)\end{array}$ \\
\hline Investment (in percent of GDP) & $\begin{array}{c}0.18 \\
\left(5.92^{\circ}\right)\end{array}$ & $\begin{array}{c}0.17 \\
\left(5.82^{\circ}\right)\end{array}$ & $\begin{array}{c}0.18 \\
\left(3.54^{\circ}\right)\end{array}$ & $\begin{array}{c}0.17 \\
\left(5.71^{\circ}\right)\end{array}$ & $\begin{array}{c}0.01 \\
\left(2.85^{\circ}\right)\end{array}$ & $\begin{array}{c}0.01 \\
\left(2.73^{\circ}\right)\end{array}$ \\
\hline $\begin{array}{l}\text { Government Consumption (in percent of } \\
\text { GDP) }\end{array}$ & $\begin{array}{c}-0.093 \\
\left(-1.98^{*}\right)\end{array}$ & $\begin{array}{c}-0.10 \\
\left(-2.20^{*}\right)\end{array}$ & $\begin{array}{c}-0.12 \\
(-2.03 *)\end{array}$ & $\begin{array}{c}-0.12 \\
\left(-2.64^{\circ}\right)\end{array}$ & $\begin{array}{c}-0.01 \\
(-1.11)\end{array}$ & $\begin{array}{c}-0.01 \\
(-1.06)\end{array}$ \\
\hline Rule-of-Law Index & $\begin{array}{c}0.19 \\
(2.01 *)\end{array}$ & $\begin{array}{c}0.17 \\
\left(1.83^{* *}\right)\end{array}$ & $\begin{array}{c}0.06 \\
(0.52)\end{array}$ & $\begin{array}{c}0.13 \\
(1.32)\end{array}$ & $\begin{array}{c}0.02 \\
\left(2.24^{*}\right)\end{array}$ & $\begin{array}{c}0.02 \\
\left(2.10^{*}\right)\end{array}$ \\
\hline Inflation Rate & $\begin{array}{c}-0.001 \\
\left(-3.84^{\circ}\right)\end{array}$ & $\begin{array}{c}-0.001 \\
\left(-3.98^{\circ}\right)\end{array}$ & $\begin{array}{c}-0.002 \\
\left(-3.70^{\circ}\right)\end{array}$ & $\begin{array}{l}-0.001 \\
\left(-3.86^{\circ}\right)\end{array}$ & $\begin{array}{l}-0.0001 \\
\left(-2.46^{*}\right)\end{array}$ & $\begin{array}{l}-0.0001 \\
\left(-2.68^{\circ}\right)\end{array}$ \\
\hline Growth Rate of Terms of Trade & $\begin{array}{c}4.41 \\
\left(1.93^{* *}\right)\end{array}$ & $\begin{array}{c}3.55 \\
(1.58)\end{array}$ & $\begin{array}{c}4.71 \\
(1.32)\end{array}$ & $\begin{array}{c}3.45 \\
(1.55)\end{array}$ & $\begin{array}{c}0.18 \\
(1.17)\end{array}$ & $\begin{array}{c}0.18 \\
(1.23)\end{array}$ \\
\hline Liquid Liabilities & & & $\begin{array}{c}-0.22 \\
(-0.23)\end{array}$ & & & \\
\hline Stock Market Capitalization & & & $\begin{array}{c}0.30 \\
(0.67)\end{array}$ & & & \\
\hline Political Rights & & & & $\begin{array}{l}-0.12 \\
(0.45)\end{array}$ & & \\
\hline Civil Liberties & & & & $\begin{array}{c}0.17 \\
(0.57)\end{array}$ & & \\
\hline Democracy & & & & $\begin{array}{c}-0.04 \\
(-0.45)\end{array}$ & & \\
\hline Estimation Method & OLS & OLS & OLS & OLS & GMM & GMM \\
\hline Number of countries & 106 & 106 & 76 & 105 & 102 & 102 \\
\hline Number of observations & 435 & 434 & 260 & 426 & 325 & 325 \\
\hline $\mathrm{R}^{2}$ (within) & 0.42 & 0.44 & 0.45 & 0.43 & & \\
\hline Sargan Test (p-level) & & & & & 0.45 & 0.26 \\
\hline Arellano-Bond-Test (p-level) & & & & & 0.82 & 0.73 \\
\hline
\end{tabular}

Notes:

In the OLS regressions, the dependent variable is the average GDP per capita growth rate. When estimated with GMM, the natural logarithm of per capita GDP at the end of each five-year period is employed.

A dummy for each time period is included, the OLS regressions also include a dummy for each country.

Robust (White) t-statistics are shown in parentheses:

': significant at the 1 percent level, *: significant at the 5 percent level, **: significant at the 10 percent level. 
Table 5: Per Capita GDP Growth and Economic Integration (1970-2000)

\begin{tabular}{|c|c|c|c|c|c|c|c|c|}
\hline & 1 & 2 & 3 & 4 & 5 & 6 & $7 \mathrm{a}$ & $7 \mathrm{~b}$ \\
\hline Index of Economic Integration & $\begin{array}{c}0.42 \\
\left(2.40^{*}\right)\end{array}$ & & & & $\begin{array}{c}0.04 \\
(2.37 *)\end{array}$ & & & \\
\hline Index of Actual Economic Flows & & $\begin{array}{c}0.96 \\
\left(3.92^{\circ}\right)\end{array}$ & & & & $\begin{array}{c}0.07 \\
\left(2.53^{*}\right)\end{array}$ & & \\
\hline Index of Restrictions & & & $\begin{array}{r}0.004 \\
(0.03)\end{array}$ & & & & & \\
\hline $\begin{array}{l}\text { Restrictions * Log (per capita GDP), } \\
\quad \text { (low income countries) }\end{array}$ & & & & $\begin{array}{c}-0.03 \\
(-1.20)\end{array}$ & & & $\begin{array}{l}-0.001 \\
(-0.35)\end{array}$ & $\begin{array}{l}0.001 \\
(0.21)\end{array}$ \\
\hline $\begin{array}{l}\text { Restrictions * Log (per capita GDP), } \\
\text { (middle income countries) }\end{array}$ & & & & $\begin{array}{c}0.01 \\
(0.41)\end{array}$ & & & $\begin{array}{l}0.001 \\
(0.62)\end{array}$ & $\begin{array}{l}0.001 \\
(0.64)\end{array}$ \\
\hline $\begin{array}{l}\text { Restrictions * Log (per capita GDP), } \\
\quad \text { (high income countries) }\end{array}$ & & & & $\begin{array}{c}0.09 \\
\left(3.91^{\circ}\right)\end{array}$ & & & $\begin{array}{c}0.004 \\
(1.72 * *)\end{array}$ & $\begin{array}{c}0.01 \\
\left(3.56^{\circ}\right)\end{array}$ \\
\hline $\begin{array}{l}\text { Log (per capita GDP), } \\
\text { beginning of period }\end{array}$ & $\begin{array}{l}-5.75 \\
\left(-6.94^{\circ}\right)\end{array}$ & $\begin{array}{l}-5.62 \\
\left(-6.81^{\circ}\right)\end{array}$ & $\begin{array}{c}-5.81 \\
\left(-6.73^{\circ}\right)\end{array}$ & $\begin{array}{l}-6.32 \\
\left(-7.27^{\circ}\right)\end{array}$ & $\begin{array}{c}1.34 \\
\left(3.85^{\circ}\right)\end{array}$ & $\begin{array}{l}1.38 \\
\left(4.15^{\circ}\right)\end{array}$ & $\begin{array}{l}0.86 \\
\left(3.20^{\circ}\right)\end{array}$ & $\begin{array}{c}0.69 \\
\left(6.29^{\circ}\right)\end{array}$ \\
\hline Secondary School Enrollment & $\begin{array}{c}0.03 \\
\left(3.36^{\circ}\right)\end{array}$ & $\begin{array}{c}0.03 \\
\left(3.03^{\circ}\right)\end{array}$ & $\begin{array}{c}0.03 \\
\left(2.82^{\circ}\right)\end{array}$ & $\begin{array}{c}0.02 \\
\left(2.27^{*}\right)\end{array}$ & $\begin{array}{l}-0.003 \\
(-1.11)\end{array}$ & $\begin{array}{l}-0.003 \\
(-1.26)\end{array}$ & $\begin{array}{l}-0.001 \\
(-0.44)\end{array}$ & $\begin{array}{l}0.0004 \\
(0.42)\end{array}$ \\
\hline Log (Life Expectancy) & $\begin{array}{c}0.94 \\
(0.43)\end{array}$ & $\begin{array}{c}0.77 \\
(0.28)\end{array}$ & $\begin{array}{c}1.97 \\
(0.88)\end{array}$ & $\begin{array}{c}2.09 \\
(2.27 *)\end{array}$ & $\begin{array}{c}-0.34 \\
(-1.35)\end{array}$ & $\begin{array}{l}-0.38 \\
(-1.51)\end{array}$ & $\begin{array}{l}-0.16 \\
(-1.15)\end{array}$ & $\begin{array}{c}-0.11 \\
(-0.88)\end{array}$ \\
\hline Log (Fertility Rate) & $\begin{array}{l}-1.26 \\
(-1.27)\end{array}$ & $\begin{array}{c}-1.88 \\
(-1.93 * *)\end{array}$ & $\begin{array}{c}-1.08 \\
(-1.08)\end{array}$ & $\begin{array}{c}-2.19 \\
(-2.09 *)\end{array}$ & $\begin{array}{c}-0.29 \\
\left(-2.33^{*}\right)\end{array}$ & $\begin{array}{c}-0.34 \\
\left(-2.59^{\circ}\right)\end{array}$ & $\begin{array}{c}-0.18 \\
\left(-2.25^{*}\right)\end{array}$ & $\begin{array}{c}-0.22 \\
\left(-2.59^{\circ}\right)\end{array}$ \\
\hline Investment (in percent of GDP) & $\begin{array}{c}0.16 \\
\left(5.36^{\circ}\right)\end{array}$ & $\begin{array}{c}0.17 \\
\left(5.88^{\circ}\right)\end{array}$ & $\begin{array}{c}0.18 \\
\left(5.79^{\circ}\right)\end{array}$ & $\begin{array}{c}0.20 \\
\left(6.36^{\circ}\right)\end{array}$ & $\begin{array}{c}0.01 \\
\left(2.45^{*}\right)\end{array}$ & $\begin{array}{c}0.01 \\
\left(2.75^{\circ}\right)\end{array}$ & $\begin{array}{c}0.01 \\
\left(3.73^{\circ}\right)\end{array}$ & $\begin{array}{c}0.01 \\
\left(4.35^{\circ}\right)\end{array}$ \\
\hline $\begin{array}{l}\text { Government Consumption (in percent } \\
\text { of GDP) }\end{array}$ & $\begin{array}{c}-0.11 \\
\left(-2.24^{*}\right)\end{array}$ & $\begin{array}{c}-0.10 \\
\left(-2.18^{*}\right)\end{array}$ & $\begin{array}{c}-0.10 \\
(-2.08 *)\end{array}$ & $\begin{array}{c}-0.11 \\
\left(-2.44^{*}\right)\end{array}$ & $\begin{array}{c}-0.01 \\
(-1.08)\end{array}$ & $\begin{array}{c}-0.01 \\
(-1.02)\end{array}$ & $\begin{array}{l}-0.001 \\
(-1.21)\end{array}$ & $\begin{array}{c}-0.01 \\
(-1.54)\end{array}$ \\
\hline Rule-of-Law Index & $\begin{array}{c}0.20 \\
(2.02 *)\end{array}$ & $\begin{array}{c}0.20 \\
\left(2.14^{*}\right)\end{array}$ & $\begin{array}{c}0.24 \\
\left(2.35^{*}\right)\end{array}$ & $\begin{array}{c}0.18 \\
(1.82 * *)\end{array}$ & $\begin{array}{c}0.02 \\
(2.34 *)\end{array}$ & $\begin{array}{c}0.02 \\
\left(2.27^{*}\right)\end{array}$ & $\begin{array}{c}0.02 \\
\left(2.30^{*}\right)\end{array}$ & $\begin{array}{c}0.01 \\
\left(2.54^{*}\right)\end{array}$ \\
\hline Inflation Rate & $\begin{array}{c}-0.001 \\
\left(-3.75^{\circ}\right)\end{array}$ & $\begin{array}{c}-0.001 \\
\left(-3.71^{\circ}\right)\end{array}$ & $\begin{array}{c}-0.001 \\
\left(-3.81^{\circ}\right)\end{array}$ & $\begin{array}{c}-0.001 \\
\left(-3.66^{\circ}\right)\end{array}$ & $\begin{array}{c}-0.0001 \\
(-2.42 *)\end{array}$ & $\begin{array}{l}-0.0001 \\
\left(-2.32^{*}\right)\end{array}$ & $\begin{array}{l}-0.0001 \\
\left(-3.62^{\circ}\right)\end{array}$ & $\begin{array}{l}-0.0001 \\
\left(-3.99^{\circ}\right)\end{array}$ \\
\hline Growth Rate of Terms of Trade & $\begin{array}{c}4.23 \\
(1.83 * *)\end{array}$ & $\begin{array}{c}2.69 \\
(1.19)\end{array}$ & $\begin{array}{c}4.41 \\
\left(1.88^{* *}\right)\end{array}$ & $\begin{array}{c}3.54 \\
(1.58)\end{array}$ & $\begin{array}{c}0.21 \\
(1.33)\end{array}$ & $\begin{array}{c}0.12 \\
(0.71)\end{array}$ & $\begin{array}{c}0.14 \\
(1.07)\end{array}$ & $\begin{array}{c}0.08 \\
(0.63)\end{array}$ \\
\hline Estimation Method & OLS & OLS & OLS & OLS & GMM & GMM & GMM & GMM \\
\hline Number of countries & 106 & 106 & 105 & 105 & 102 & 102 & 100 & 100 \\
\hline Number of observations & 435 & 435 & 463 & 423 & 326 & 326 & 314 & 314 \\
\hline $\mathrm{R}^{2}$ (within) & 0.43 & 0.46 & 0.37 & 0.46 & & & & \\
\hline Sargan Test (p-level) & & & & & 0.29 & 0.35 & 0.03 & 0.28 \\
\hline Arellano-Bond-Test (p-level) & & & & & 0.85 & 0.96 & 0.22 & 0.16 \\
\hline
\end{tabular}

Notes:

In the OLS regressions, the dependent variable is the average GDP per capita growth rate. When estimated with GMM, the natural logarithm of per capita GDP at the end of each five-year period is employed.

A dummy for each time period is included, the OLS regressions also include a dummy for each country. Column $7 \mathrm{~b}$ treats the interaction terms as predetermined, while all variables are treated as exogenous in the other columns.

Robust (White) t-statistics are shown in parentheses:

${ }^{\circ}$ : significant at the 1 percent level

*: significant at the 5 percent level

**: significant at the 10 percent level. 
Table 6: Per Capita GDP Growth and Political Integration (1970-2000)

\begin{tabular}{|l|c|c|}
\hline & 1 & 2 \\
\hline Index of Political Integration & 0.003 & 0.01 \\
Log (per capita GDP), beginning of period & $(0.02)$ & $(0.65)$ \\
Secondary School Enrollment & -5.75 & 1.40 \\
& $\left(-6.85^{\circ}\right)$ & $\left(3.88^{\circ}\right)$ \\
Log (Life Expectancy) & 0.03 & -0.004 \\
& $\left(3.10^{\circ}\right)$ & $(-1.40)$ \\
Log (Fertility Rate) & 1.86 & -0.38 \\
& $(0.84)$ & $(-1.40)$ \\
Investment (in percent of GDP) & -1.37 & -0.28 \\
& $(-1.39)$ & $\left(-2.23^{*}\right)$ \\
Government Consumption (in percent of & 0.18 & 0.01 \\
GDP) & $\left(5.93^{\circ}\right)$ & $\left(2.83^{\circ}\right)$ \\
Rule-of-Law Index & -0.09 & -0.01 \\
& $\left(-1.98^{*}\right)$ & $(-1.09)$ \\
Inflation Rate & 0.19 & 0.02 \\
& $(2.00)$ & $\left(2.40^{*}\right)$ \\
Growth Rate of Terms of Trade & -0.001 & -0.0001 \\
& $\left(-3.83^{\circ}\right)$ & $\left(-2.23^{*}\right)$ \\
Estimation Method & 4.41 & 0.23 \\
Number of countries & $\left(1.92^{* *}\right)$ & $(1.37)$ \\
Number of observations & OLS & GMM \\
$\mathrm{R}^{2}$ (within) & 106 & 102 \\
Sargan Test (p-level) & 435 & 326 \\
Arellano-Bond-Test (p-level) & 0.42 & \\
\hline
\end{tabular}

Notes:

In the OLS regressions, the dependent variable is the average GDP per capita growth rate. When estimated with GMM, the natural logarithm of per capita GDP at the end of each five-year period is employed.

A dummy for each time period is included, the OLS regressions also include a dummy for each country.

Robust (White) t-statistics are shown in parentheses:

${ }^{\circ}$ : significant at the 1 percent level

*: significant at the 5 percent level

**: significant at the 10 percent level. 
Table 7: Per Capita GDP Growth and Social Integration (1970-2000)

\begin{tabular}{|c|c|c|c|c|c|c|c|}
\hline & 1 & 2 & 3 & 4 & 5 & $6 a$ & $6 \mathrm{~b}$ \\
\hline Index of Social Integration & $\begin{array}{c}0.83 \\
\left(3.69^{\circ}\right)\end{array}$ & & & $\begin{array}{c}0.03 \\
(1.19)\end{array}$ & & & \\
\hline Index of Personal Contact & & $\begin{array}{c}0.29 \\
\left(1.86^{* *}\right)\end{array}$ & & & $\begin{array}{c}0.01 \\
(0.64)\end{array}$ & & \\
\hline Index of Information Flows & & & $\begin{array}{r}1.25 \\
\left(3.70^{\circ}\right)\end{array}$ & & & $\begin{array}{c}0.03 \\
(0.75)\end{array}$ & $\begin{array}{c}0.12 \\
\left(3.15^{\circ}\right)\end{array}$ \\
\hline Log (per capita GDP), beginning of period & $\begin{array}{c}-6.13 \\
\left(-7.64^{\circ}\right)\end{array}$ & $\begin{array}{c}-6.45 \\
\left(-7.64^{\circ}\right)\end{array}$ & $\begin{array}{c}-6.31 \\
\left(-7.77^{\circ}\right)\end{array}$ & $\begin{array}{c}1.23 \\
\left(3.33^{\circ}\right)\end{array}$ & $\begin{array}{c}1.15 \\
\left(3.16^{\circ}\right)\end{array}$ & $\begin{array}{c}1.16 \\
\left(3.08^{\circ}\right)\end{array}$ & $\begin{array}{c}0.75 \\
\left(4.67^{\circ}\right)\end{array}$ \\
\hline Secondary School Enrollment & $\begin{array}{c}0.02 \\
\left(2.08^{*}\right)\end{array}$ & $\begin{array}{c}0.02 \\
(1.74 * *)\end{array}$ & $\begin{array}{c}0.02 \\
(2.11 *)\end{array}$ & $\begin{array}{l}-0.002 \\
(-1.20)\end{array}$ & $\begin{array}{l}-0.002 \\
(-0.93)\end{array}$ & $\begin{array}{l}-0.002 \\
(-1.07)\end{array}$ & $\begin{array}{l}-0.001 \\
(-0.90)\end{array}$ \\
\hline Log (Life Expectancy) & $\begin{array}{c}1.35 \\
(0.60)\end{array}$ & $\begin{array}{c}2.23 \\
(1.03)\end{array}$ & $\begin{array}{r}1.22 \\
(0.55)\end{array}$ & $\left|\begin{array}{c}-0.27 \\
\left(-1.66^{* *}\right)\end{array}\right|$ & $\begin{array}{l}-0.18 \\
(-0.79)\end{array}$ & $\begin{array}{l}-0.31 \\
(-1.45)\end{array}$ & $\begin{array}{c}-0.28 \\
\left(-2.16^{*}\right)\end{array}$ \\
\hline Log (Fertility Rate) & $\begin{array}{c}-2.49 \\
\left(-2.27^{*}\right)\end{array}$ & $\begin{array}{l}-0.88 \\
(-0.89)\end{array}$ & $\begin{array}{c}-3.24 \\
\left(-2.74^{\circ}\right)\end{array}$ & $\begin{array}{c}-0.28 \\
\left(-2.55^{*}\right)\end{array}$ & $\begin{array}{c}-0.23 \\
\left(-1.86^{* *}\right)\end{array}$ & $\begin{array}{c}-0.27 \\
\left(-2.60^{\circ}\right)\end{array}$ & $\begin{array}{c}-0.30 \\
\left(-3.50^{\circ}\right)\end{array}$ \\
\hline Investment (in percent of GDP) & $\begin{array}{c}0.17 \\
\left(6.07^{\circ}\right)\end{array}$ & $\begin{array}{c}0.16 \\
\left(5.13^{\circ}\right)\end{array}$ & $\begin{array}{c}0.18 \\
\left(6.15^{\circ}\right)\end{array}$ & $\begin{array}{c}0.01 \\
\left(3.10^{\circ}\right)\end{array}$ & $\begin{array}{c}0.01 \\
\left(2.75^{\circ}\right)\end{array}$ & $\begin{array}{c}0.01 \\
\left(3.24^{\circ}\right)\end{array}$ & $\begin{array}{c}0.01 \\
\left(4.44^{\circ}\right)\end{array}$ \\
\hline $\begin{array}{l}\text { Government Consumption (in percent of } \\
\text { GDP) }\end{array}$ & $\begin{array}{c}-0.09 \\
(-1.93 * *)\end{array}$ & $\begin{array}{c}-0.83 \\
(-1.70 * *)\end{array}$ & $\begin{array}{c}-0.10 \\
\left(-2.17^{*}\right)\end{array}$ & $\begin{array}{l}-0.01 \\
(-1.06)\end{array}$ & $\begin{array}{c}-0.01 \\
(-0.82)\end{array}$ & $\begin{array}{l}-0.01 \\
(-1.11)\end{array}$ & $\begin{array}{l}-0.01 \\
(-1.31)\end{array}$ \\
\hline Rule-of-Law Index & $\begin{array}{c}0.16 \\
(1.65 * *)\end{array}$ & $\begin{array}{c}0.17 \\
(1.71 * *)\end{array}$ & $\begin{array}{r}0.15 \\
(1.50)\end{array}$ & $\begin{array}{c}0.02 \\
\left(2.18^{*}\right)\end{array}$ & $\begin{array}{c}0.02 \\
\left(2.37^{*}\right)\end{array}$ & $\begin{array}{c}0.02 \\
\left(2.15^{*}\right)\end{array}$ & $\begin{array}{c}0.01 \\
\left(1.73^{* *}\right)\end{array}$ \\
\hline Inflation Rate & $\begin{array}{c}-0.001 \\
\left(-4.10^{\circ}\right)\end{array}$ & $\begin{array}{c}-0.01 \\
(-2.43 *)\end{array}$ & $\begin{array}{c}-0.001 \\
\left(-3.81^{\circ}\right)\end{array}$ & $\begin{array}{l}-0.0001 \\
(-2.53 *)\end{array}$ & $\begin{array}{l}-0.0001 \\
\left(-2.18^{*}\right)\end{array}$ & $\begin{array}{l}-0.0001 \\
\left(-2.71^{\circ}\right)\end{array}$ & $\begin{array}{l}-0.0001 \\
\left(-3.85^{\circ}\right)\end{array}$ \\
\hline Growth Rate of Terms of Trade & $\begin{array}{c}3.60 \\
(1.64)\end{array}$ & $\begin{array}{r}2.16 \\
(0.94)\end{array}$ & $\begin{array}{c}3.99 \\
\left(1.78^{* *}\right)\end{array}$ & $\begin{array}{c}0.24 \\
(1.36)\end{array}$ & $\begin{array}{c}0.12 \\
(0.74)\end{array}$ & $\begin{array}{c}0.21 \\
(1.44)\end{array}$ & $\begin{array}{c}0.13 \\
(1.09)\end{array}$ \\
\hline Estimation Method & OLS & OLS & OLS & GMM & GMM & GMM & GMM \\
\hline Number of countries & 106 & 105 & 106 & 102 & 99 & 102 & 102 \\
\hline Number of observations & 434 & 403 & 435 & 325 & 294 & 326 & 326 \\
\hline $\mathrm{R}^{2}$ (within) & 0.44 & 0.45 & 0.44 & & & & \\
\hline Sargan Test (p-level) & & & & 0.23 & 0.17 & 0.07 & 0.12 \\
\hline Arellano-Bond-Test (p-level) & & & & 0.67 & 0.57 & 0.53 & 0.13 \\
\hline
\end{tabular}

Notes:

In the OLS regressions, the dependent variable is the average GDP per capita growth rate. When estimated with GMM, the natural logarithm of per capita GDP at the end of each five-year period is employed.

A dummy for each time period is included, the OLS regressions also include a dummy for each country. Column $6 \mathrm{~b}$ treats information flows as predetermined, while all variables are treated as exogenous in the other columns.

Robust (White) t-statistics are shown in parentheses:

${ }^{\circ}$ : significant at the 1 percent level

*: significant at the 5 percent level

**: significant at the 10 percent level. 
Table 8: Robustness Analysis

\begin{tabular}{|c|c|c|c|c|c|c|c|c|}
\hline & \multicolumn{2}{|c|}{ Overall Index } & \multicolumn{2}{|c|}{$\begin{array}{l}\text { Actual Economic } \\
\text { Flows }\end{array}$} & \multicolumn{2}{|c|}{$\begin{array}{l}\text { Restrictions * } \\
\text { Log (per capita } \\
\text { GDP), } \\
\text { (high income } \\
\text { countries) }\end{array}$} & \multicolumn{2}{|c|}{$\begin{array}{l}\text { Information } \\
\text { Flows }\end{array}$} \\
\hline & OLS & GMM & OLS & GMM & OLS & GMM & OLS & GMM \\
\hline $\begin{array}{l}\text { Least Absolute } \\
\text { Value Regression }\end{array}$ & 10 & & 5 & & 1 & & insig. & \\
\hline $\begin{array}{l}\text { Without East } \\
\text { Asian Countries }\end{array}$ & 1 & 10 & 1 & 10 & 1 & 1 & 1 & 10 \\
\hline $\begin{array}{l}\text { Without Latin } \\
\text { American } \\
\text { Countries }\end{array}$ & 5 & insig. & 1 & 5 & 1 & 1 & 1 & 10 \\
\hline $\begin{array}{l}\text { Without Sub } \\
\text { Saharan Africa }\end{array}$ & 10 & 1 & 1 & 5 & 5 & 5 & 1 & 5 \\
\hline $\begin{array}{l}\text { Without OECD } \\
\text { Countries }\end{array}$ & 5 & 1 & 1 & 10 & - & - & insig. & insig. \\
\hline $\begin{array}{l}\text { Without China } \\
\text { and India }\end{array}$ & 1 & 5 & 1 & 5 & 1 & 1 & 1 & 10 \\
\hline $\begin{array}{l}\text { Black Market } \\
\text { Premium }\end{array}$ & 1 & 10 & 1 & 1 & 1 & 1 & 1 & insig. \\
\hline $\begin{array}{l}\text { Overall Budget } \\
\text { Balance }\end{array}$ & 5 & insig. & 1 & 5 & 1 & 5 & 1 & insig. \\
\hline $\begin{array}{l}\text { Political } \\
\text { Instability }\end{array}$ & 5 & insig. & 1 & 5 & 1 & 5 & 1 & insig. \\
\hline Theil Index & 5 & 10 & 1 & 10 & 1 & 1 & 1 & insig. \\
\hline Banking Quality & $5^{2}$ & 5 & 1 & 1 & insig. & insig. & insig. & insig. \\
\hline $\begin{array}{l}\text { Institutional } \\
\text { Variables }\end{array}$ & $1^{2}$ & insig. & 1 & 5 & 1 & 1 & 1 & 5 \\
\hline $\begin{array}{l}\text { Re-weighted } \\
\text { Indexes }\end{array}$ & 1 & 10 & 1 & 10 & 1 & 5 & 1 & 5 \\
\hline
\end{tabular}

Notes:

In the OLS regressions, the dependent variable is the average GDP per capita growth rate. When estimated with GMM, the natural logarithm of per capita GDP at the end of each fiveyear period is employed.

Numbers indicate the significance level of the respective index. All regressions include the covariates of Table 4, column 1.

${ }^{1}$ No category has been omitted, even if no data for the index has been available in a certain period. Instead, data from the next period available have been used.

${ }^{2}$ This corresponds to the results of Table 4 . 


\section{Appendix A: Definitions}

Trade (in percent of GDP): Sum of exports and imports of goods and services measured as a share of gross domestic product.

Foreign Direct Investment (in percent of GDP): Sum of the absolute values of inflows and outflows of foreign direct investment recorded in the balance of payments.

Portfolio Investment (in percent of GDP): Sum of absolute values of portfolio investment assets and portfolio investment liabilities.

Income (in percent of GDP): Income payments refer to employee compensation paid to nonresident workers and investment income.

Hidden Import Barriers: barriers other than published tariffs and quotas.

Mean Tariff Rate: The formula used to calculate the 0-to-10 rating for each country was: $\left(v_{\max }-\mathrm{vi}_{\mathrm{i}}\right) /\left(\mathrm{vmax}-\mathrm{vm}_{\min }\right)$ multiplied by $10 . \mathrm{V}_{\mathrm{i}}$ represents the country's mean tariff rate. The values for $\mathrm{vmin}$ and $\mathrm{vmax}$ were set at $0 \%$ and $50 \%$, respectively. This formula will allocate a rating of 10 to countries that do not impose tariffs. As the mean tariff rate increases, countries are assigned lower ratings. The rating will decline toward zero as the mean tariff rate approaches $50 \%$.

Taxes on International Trade (in percent of current revenue): Include import duties, export duties, profits of export or import monopolies, exchange profits, and exchange taxes.

Capital Account Restrictions: The index is based on the IMF's Annual Report on Exchange Arrangements and Exchange Restrictions and includes 13 different types of capital controls. It is constructed by subtracting the number of restriction from 13 and multiplying the result by 10 .

Embassies in Country: Absolute number.

Membership in International Organizations: Absolute number.

Participation in UN Security Council Missions: Absolute number of missions a country participated.

Outgoing telephone traffic: Measured in minutes per 1000 population.

Transfers (in percent of GDP): Measures inflows and outflows of goods, services, income, or financial items without a quid pro quo.

International Tourism (as a share of population): Sum of arrivals and departures.

Telephone Average Costs of Call to USA: Cost of a three-minute peak rate call from the country to the United States.

Foreign Population (in percent of total population): Foreign (or foreign-born) population is the number of foreign or foreign-born residents in a country.

Telephone Mainlines (per 1000 people): Telephone mainlines are telephone lines connecting a customer's equipment to the public switched telephone network.

Internet Hosts (per capita).

Internet Users (as a share of population): Internet users are people with access to the worldwide network.

Cable Television (per 1000 people): Cable television subscribers are households that subscribe to a multichannel television service delivered by a fixed line connection.

Daily Newspapers (per 1000 people): Daily newspapers refer to those published at least four times a week.

Radios (per 1000 people): Radios refer to radio receivers in use for broadcasts to the general public. 
Number of McDonald's Restaurants (per capita).

GDP per capita growth: Annual percentage growth rate of GDP per capita based on constant local currency.

Log (per capita GDP): GDP per capita is gross domestic product divided by midyear population. Data are for the end of each five-year period.

Secondary School Enrollment: Gross enrollment ratio is the ratio of total enrollment, regardless of age, to the population of the age group that officially corresponds to the level of education shown. Secondary education completes the provision of basic education that began at the primary level.

Log (Life Expectancy): Life expectancy at birth indicates the number of years a newborn infant would live if prevailing patterns of mortality at the time of its birth were to stay the same throughout its life.

Log (Fertility Rate): Represents the number of children that would be born to a woman if she were to live to the end of her childbearing years and bear children in accordance with prevailing age-specific fertility rates.

Investment (in percent of GDP): Gross domestic investment.

Government Consumption (in percent of GDP): All government current expenditures for purchases of goods and services (including compensation of employees).

Rule-of-Law Index: Measures the quality of the legal system and property rights.

Inflation Rate: Measured by the consumer price index. The Laspeyres formula is generally used.

Growth Rate of Terms of Trade: Base year is 1995.

Liquid Liabilities: Liquid Liabilities to GDP equals currency plus demand and interest-bearing liabilities of banks and other financial intermediaries divided by GDP.

Stock Market Capitalization: Equals the value of listed shares divided by GDP.

Political Rights: rates political rights with 1 representing the most free and 7 the least free.

Civil Liberties: rates civil liberties with 1 representing the most free and 7 the least free.

Democracy: 0-10 $(0=$ low; $10=$ high $)$ democracy score. Measures the general openness of political institutions.

Black Market Premium: (Parallel Exchange Rate/Official Exchange Rate-1)*100.

Overall Budget Balance (in percent of GDP): Includes grants.

Political Instability: Index constructed with principal components analysis. The weights obtained for the components are 0.08 (assassination), 0.1 (strikes), 0.25 (guerrilla warfare), 0.15 (crisis), 0.16 (riots) and 0.27 (revolutions).

Theil Index: The Theil inequality index is a weighted geometric average of income relatives. 
Appendix B: Descriptive Statistics and Data Sources

\begin{tabular}{|c|c|c|c|c|}
\hline Variable & Data Source & & Mean & Std. Dev. \\
\hline Trade Index & World Bank (2002a) & $\begin{array}{l}\text { overall } \\
\text { between } \\
\text { within }\end{array}$ & 1.91 & $\begin{array}{l}1.44 \\
1.36 \\
0.48\end{array}$ \\
\hline $\begin{array}{l}\text { Foreign Direct } \\
\text { Investment Index }\end{array}$ & World Bank (2002a) & \begin{tabular}{|l|} 
overall \\
between \\
within \\
\end{tabular} & 1.24 & $\begin{array}{l}1.54 \\
1.31 \\
0.93 \\
\end{array}$ \\
\hline $\begin{array}{l}\text { Portfolio Investment } \\
\text { Index }\end{array}$ & IMF (2002) & $\begin{array}{l}\text { overall } \\
\text { between } \\
\text { within }\end{array}$ & 1.48 & $\begin{array}{l}1.82 \\
1.32 \\
1.17 \\
\end{array}$ \\
\hline Income Index & World Bank (2002a) & $\begin{array}{l}\text { overall } \\
\text { between } \\
\text { within }\end{array}$ & 0.88 & $\begin{array}{l}1.43 \\
1.22 \\
0.98 \\
\end{array}$ \\
\hline $\begin{array}{l}\text { Hidden Import } \\
\text { Barriers Index }\end{array}$ & $\begin{array}{l}\text { Gwartney and } \\
\text { Lawson (2002) }\end{array}$ & $\begin{array}{l}\text { overall } \\
\text { between } \\
\text { within }\end{array}$ & 6.47 & $\begin{array}{l}1.82 \\
1.82 \\
0.44\end{array}$ \\
\hline Mean Tariff Rate Index & $\begin{array}{l}\text { Gwartney and } \\
\text { Lawson (2002) }\end{array}$ & $\begin{array}{l}\text { overall } \\
\text { between } \\
\text { within }\end{array}$ & 6.32 & $\begin{array}{l}2.66 \\
2.15 \\
1.49 \\
\end{array}$ \\
\hline $\begin{array}{l}\text { Taxes on International } \\
\text { Trade Index }\end{array}$ & World Bank (2002a) & $\begin{array}{l}\text { overall } \\
\text { between } \\
\text { within }\end{array}$ & 7.42 & $\begin{array}{l}2.39 \\
2.29 \\
0.91 \\
\end{array}$ \\
\hline $\begin{array}{l}\text { Capital Account } \\
\text { Restrictions Index }\end{array}$ & $\begin{array}{l}\text { Gwartney and } \\
\text { Lawson (2002) }\end{array}$ & $\begin{array}{l}\text { overall } \\
\text { between } \\
\text { within }\end{array}$ & 3.10 & $\begin{array}{l}3.32 \\
2.70 \\
1.92 \\
\end{array}$ \\
\hline $\begin{array}{l}\text { Embassies in Country } \\
\text { Index }\end{array}$ & $\begin{array}{l}\text { Europa World } \\
\text { Yearbook } \\
\text { (various years) }\end{array}$ & $\begin{array}{l}\text { overall } \\
\text { between } \\
\text { within }\end{array}$ & 3.51 & $\begin{array}{l}2.47 \\
2.18 \\
1.18 \\
\end{array}$ \\
\hline $\begin{array}{l}\text { Membership in } \\
\text { International } \\
\text { Organizations Index }\end{array}$ & $\begin{array}{l}\text { Union of International } \\
\text { Associations } \\
\text { (various years) }\end{array}$ & $\begin{array}{l}\text { overall } \\
\text { between } \\
\text { within }\end{array}$ & 4.41 & $\begin{array}{l}1.92 \\
1.63 \\
1.01\end{array}$ \\
\hline $\begin{array}{l}\text { Participation in UN } \\
\text { Security Council } \\
\text { Missions Index }\end{array}$ & $\begin{array}{l}\text { Department of } \\
\text { Peacekeeping } \\
\text { Operations, UN }\end{array}$ & $\begin{array}{l}\text { overall } \\
\text { between } \\
\text { within } \\
\end{array}$ & 1.49 & $\begin{array}{l}2.33 \\
2.07 \\
1.09 \\
\end{array}$ \\
\hline $\begin{array}{l}\text { Outgoing Telephone } \\
\text { Traffic Index }\end{array}$ & World Bank (2002a) & $\begin{array}{l}\text { overall } \\
\text { between } \\
\text { within } \\
\end{array}$ & 0.68 & $\begin{array}{l}1.38 \\
1.22 \\
0.40 \\
\end{array}$ \\
\hline Transfers Index & World Bank (2002a) & $\begin{array}{l}\text { overall } \\
\text { between } \\
\text { within } \\
\end{array}$ & 1.95 & $\begin{array}{l}2.09 \\
1.89 \\
1.11 \\
\end{array}$ \\
\hline $\begin{array}{l}\text { International Tourism } \\
\text { Index }\end{array}$ & World Bank (2002a) & $\begin{array}{l}\text { overall } \\
\text { between } \\
\text { within } \\
\end{array}$ & 1.62 & $\begin{array}{l}2.11 \\
1.95 \\
0.58 \\
\end{array}$ \\
\hline $\begin{array}{l}\text { Telephone Average } \\
\text { Costs of Call to USA } \\
\text { Index }\end{array}$ & World Bank (2002a) & $\begin{array}{l}\text { overall } \\
\text { between } \\
\text { within } \\
\end{array}$ & 7.92 & $\begin{array}{l}1.84 \\
1.84 \\
0.00 \\
\end{array}$ \\
\hline Internet Hosts Index & $\begin{array}{l}\text { International } \\
\text { Telecommunications } \\
\text { Union }\end{array}$ & $\begin{array}{l}\text { overall } \\
\text { between } \\
\text { within }\end{array}$ & 0.96 & $\begin{array}{l}1.77 \\
1.75 \\
0.31 \\
\end{array}$ \\
\hline
\end{tabular}




\begin{tabular}{|c|c|c|c|c|}
\hline Variable & Data Source & & Mean & Std. Dev. \\
\hline Internet Users Index & World Bank (2002a) & $\begin{array}{l}\text { overall } \\
\text { between } \\
\text { within }\end{array}$ & 0.32 & $\begin{array}{l}1.14 \\
0.60 \\
0.98\end{array}$ \\
\hline $\begin{array}{l}\text { Cable Television } \\
\text { Index }\end{array}$ & World Bank (2002a) & $\begin{array}{l}\text { overall } \\
\text { between } \\
\text { within }\end{array}$ & 1.37 & $\begin{array}{l}2.40 \\
1.93 \\
0.84\end{array}$ \\
\hline $\begin{array}{l}\text { Daily Newspapers } \\
\text { Index }\end{array}$ & World Bank (2002a) & $\begin{array}{l}\text { overall } \\
\text { between } \\
\text { within }\end{array}$ & 1.68 & $\begin{array}{l}2.06 \\
1.98 \\
0.41 \\
\end{array}$ \\
\hline Radios Index & World Bank (2002a) & $\begin{array}{l}\text { overall } \\
\text { between } \\
\text { within } \\
\end{array}$ & 1.72 & $\begin{array}{l}1.58 \\
1.50 \\
0.50 \\
\end{array}$ \\
\hline McDonald's Index & $\begin{array}{l}\text { McDonald's } \\
\text { Corporation }\end{array}$ & $\begin{array}{l}\text { overall } \\
\text { between } \\
\text { within }\end{array}$ & 1.09 & $\begin{array}{l}1.89 \\
1.85 \\
0.41\end{array}$ \\
\hline $\begin{array}{l}\text { GDP per capita } \\
\text { growth rate }\end{array}$ & World Bank (2002a) & $\begin{array}{l}\text { overall } \\
\text { between } \\
\text { within } \\
\end{array}$ & 1.52 & $\begin{array}{l}3.30 \\
1.96 \\
2.67 \\
\end{array}$ \\
\hline Log (per capita GDP) & World Bank (2002a) & $\begin{array}{l}\text { overall } \\
\text { between } \\
\text { within } \\
\end{array}$ & 7.79 & $\begin{array}{l}1.58 \\
1.56 \\
0.21 \\
\end{array}$ \\
\hline $\begin{array}{l}\text { Secondary School } \\
\text { Enrollment }\end{array}$ & World Bank (2002a) & $\begin{array}{l}\text { overall } \\
\text { between } \\
\text { within } \\
\end{array}$ & 56.55 & $\begin{array}{l}32.93 \\
31.09 \\
11.20 \\
\end{array}$ \\
\hline $\begin{array}{l}\text { Log (Life } \\
\text { Expectancy) }\end{array}$ & World Bank (2002a) & $\begin{array}{l}\text { overall } \\
\text { between } \\
\text { within } \\
\end{array}$ & 4.14 & $\begin{array}{l}0.19 \\
0.18 \\
0.05 \\
\end{array}$ \\
\hline Log (Fertility Rate) & World Bank (2002a) & $\begin{array}{l}\text { overall } \\
\text { between } \\
\text { within } \\
\end{array}$ & 1.22 & $\begin{array}{l}0.55 \\
0.52 \\
0.18 \\
\end{array}$ \\
\hline $\begin{array}{l}\text { Investment (in } \\
\text { percent of GDP) }\end{array}$ & $\begin{array}{l}\text { Global Development } \\
\text { Network Growth } \\
\text { Database }\end{array}$ & $\begin{array}{l}\text { overall } \\
\text { between } \\
\text { within }\end{array}$ & 22.48 & $\begin{array}{l}7.21 \\
5.69 \\
4.38 \\
\end{array}$ \\
\hline $\begin{array}{l}\text { Government } \\
\text { consumption (in } \\
\text { percent of GDP) }\end{array}$ & World Bank (2002a) & $\begin{array}{l}\text { overall } \\
\text { between } \\
\text { within } \\
\end{array}$ & 15.46 & $\begin{array}{l}5.92 \\
5.26 \\
2.81 \\
\end{array}$ \\
\hline Rule-of-Law Index & $\begin{array}{l}\text { Gwartney and } \\
\text { Lawson (2002) }\end{array}$ & $\begin{array}{l}\text { overall } \\
\text { between } \\
\text { within } \\
\end{array}$ & 5.47 & $\begin{array}{l}1.96 \\
1.60 \\
1.06 \\
\end{array}$ \\
\hline Inflation Rate & World Bank (2002a) & $\begin{array}{l}\text { overall } \\
\text { between } \\
\text { within } \\
\end{array}$ & 54.86 & $\begin{array}{l}368.39 \\
180.43 \\
325.48 \\
\end{array}$ \\
\hline $\begin{array}{l}\text { Growth Rate of } \\
\text { Terms of Trade }\end{array}$ & World Bank (2002a) & $\begin{array}{l}\text { overall } \\
\text { between } \\
\text { within }\end{array}$ & 0.0034 & $\begin{array}{l}0.0589 \\
0.0277 \\
0.0539\end{array}$ \\
\hline Liquid Liabilities & Beck et al. (1999) & $\begin{array}{l}\text { overall } \\
\text { between } \\
\text { within } \\
\end{array}$ & 0.46 & $\begin{array}{l}0.31 \\
0.31 \\
0.13\end{array}$ \\
\hline $\begin{array}{l}\text { Stock Market } \\
\text { Capitalization }\end{array}$ & Beck et al. (1999) & $\begin{array}{l}\text { overall } \\
\text { between } \\
\text { within }\end{array}$ & 0.33 & $\begin{array}{l}0.45 \\
0.36 \\
0.24\end{array}$ \\
\hline
\end{tabular}




\begin{tabular}{|c|c|c|c|c|}
\hline Variable & Data Source & & Mean & Std. Dev. \\
\hline Political Rights & Gastil (2000) & $\begin{array}{l}\text { overall } \\
\text { between } \\
\text { within }\end{array}$ & 3.75 & $\begin{array}{l}2.18 \\
1.90 \\
1.06\end{array}$ \\
\hline Civil Liberties & Gastil (2000) & $\begin{array}{l}\text { overall } \\
\text { between } \\
\text { within }\end{array}$ & 3.80 & $\begin{array}{l}1.88 \\
1.69 \\
0.83 \\
\end{array}$ \\
\hline Democracy & $\begin{array}{l}\text { Marshall and Jaggers } \\
(2000)\end{array}$ & $\begin{array}{l}\text { overall } \\
\text { between } \\
\text { within }\end{array}$ & 4.68 & $\begin{array}{l}4.23 \\
3.77 \\
1.93\end{array}$ \\
\hline $\begin{array}{l}\text { Black Market } \\
\text { Premium }\end{array}$ & $\begin{array}{l}\text { Global Development } \\
\text { Network Growth } \\
\text { Database }\end{array}$ & $\begin{array}{l}\text { overall } \\
\text { between } \\
\text { within }\end{array}$ & 143.68 & $\begin{array}{r}2109.66 \\
4615.41 \\
411.32\end{array}$ \\
\hline $\begin{array}{l}\text { Overall Budget } \\
\text { Balance }\end{array}$ & World Bank (2002a) & $\begin{array}{l}\text { overall } \\
\text { between } \\
\text { within }\end{array}$ & -3.33 & $\begin{array}{l}5.25 \\
4.11 \\
3.55 \\
\end{array}$ \\
\hline Political Instability & $\begin{array}{l}\text { Global Development } \\
\text { Network Growth } \\
\text { Database }\end{array}$ & $\begin{array}{l}\text { overall } \\
\text { between } \\
\text { within }\end{array}$ & 0.23 & $\begin{array}{l}0.37 \\
0.27 \\
0.25\end{array}$ \\
\hline Theil Index & $\begin{array}{l}\text { University of Texas } \\
\text { Inequality Project }\end{array}$ & $\begin{array}{l}\text { overall } \\
\text { between } \\
\text { within }\end{array}$ & 0.05 & $\begin{array}{l}0.05 \\
0.05 \\
0.03\end{array}$ \\
\hline
\end{tabular}




\section{Already published}

\begin{tabular}{|l|l|}
\hline No. & Title \\
\hline 1 & $\begin{array}{l}\text { IMF and Economic Growth: The Effects of } \\
\text { Programs, Loans, and Compliance with } \\
\text { Conditionality } \\
\text { Do gasoline prices converge in a unified } \\
\text { Europe with non-harmonized tax rates? } \\
\text { Is There A Causal Link between Currency } \\
\text { and Debt Crisis? }\end{array}$ \\
\hline 3 & $\begin{array}{l}\text { What Determines Differences in Foreign } \\
\text { Bank Efficiency? Australien Evidence } \\
\text { Market oriented institutions and policies } \\
\text { and economic growth: A critical survey }\end{array}$ \\
\hline
\end{tabular}

\section{Authors}

Axel Dreher

Axel Dreher, Tim Krieger

Axel Dreher, Bernhard Herz, Volker Karb

Jan-Egbert Sturm, Barry Williams

Jakob de Haan, Susanna Lundström, Jan-Egbert Sturm 


\section{THURGAUER}

WIRTSCHAFTSINSTITUT

an der Universität Konstanz

\section{Hauptstr. 90}

$\mathrm{CH}-8280$ Kreuzlingen 2

Telefon: +41(0)71 6770510

Telefax: +41 (0)71 6770511

info@twi-kreuzlingen.ch

www.twi-kreuzlingen.ch 